\title{
The influence of semi-volatile and reactive primary emissions on the abundance and properties of global organic aerosol
}

\author{
S. H. Jathar ${ }^{1}$, S. C. Farina ${ }^{2}$, A. L. Robinson ${ }^{1,3}$, and P. J. Adams ${ }^{1,4}$ \\ ${ }^{1}$ Department of Engineering and Public Policy, Carnegie Mellon University, Pittsburgh, PA 15213, USA \\ ${ }^{2}$ Department of Chemical Engineering, Carnegie Mellon University, Pittsburgh, PA 15213, USA \\ ${ }^{3}$ Department of Mechanical Engineering, Carnegie Mellon University, Pittsburgh, PA 15213, USA \\ ${ }^{4}$ Department of Civil and Environmental Engineering, Carnegie Mellon University, Pittsburgh, PA 15213, USA
}

Received: 16 January 2011 - Published in Atmos. Chem. Phys. Discuss.: 15 February 2011

Revised: 20 June 2011 - Accepted: 17 July 2011 - Published: 3 August 2011

\begin{abstract}
Semi-volatile and reactive primary organic aerosols are modeled on a global scale using the GISS GCM II' "unified" climate model. We employ the volatility basis set framework to simulate emissions, chemical reactions and phase partitioning of primary and secondary organic aerosol (POA and SOA). The model also incorporates the emissions and reactions of intermediate volatility organic compounds (IVOCs) as a source of organic aerosol (OA), one that has been missing in most prior work. Model predictions are evaluated against a broad set of observational constraints including mass concentrations, degree of oxygenation, volatility and isotopic composition. A traditional model that treats POA as non-volatile and non-reactive is also compared to the same set of observations to highlight the progress made in this effort. The revised model predicts a global dominance of SOA and brings the POA/SOA split into better agreement with ambient measurements. This change is due to traditionally defined POA evaporating and the evaporated vapors oxidizing to form non-traditional SOA. IVOCs (traditionally not included in chemical transport models) oxidize to form condensable products that account for a third of total OA, suggesting that global models have been missing a large source of OA. Predictions of the revised model for the SOA fraction at 17 different locations compared much better to observations than predictions from the traditional model. Modelpredicted volatility is compared with thermodenuder data collected at three different different field campaigns: FAME2008, MILAGRO-2006 and SOAR-2005. The revised model predicts the OA volatility much more closely than the traditional model. When compared against monthly averaged OA
\end{abstract}

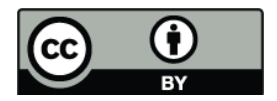

Correspondence to: P. J. Adams (peter.adams@cmu.edu) mass concentrations measured by the IMPROVE network, predictions of the revised model lie within a factor of two in summer and mostly within a factor of five during winter. A sensitivity analysis indicates that the winter comparison can be improved either by increasing POA emissions or lowering the volatility of those emissions. Model predictions of the isotopic composition of $\mathrm{OA}$ are compared against those computed via a radiocarbon isotope analysis of field samples. The contemporary fraction, on average, is slightly under-predicted $(20 \%)$ during the summer months but is a factor of two lower during the winter months. We hypothesize that the large wintertime under-prediction of surface OA mass concentrations and the contemporary fraction is due to an under-representation of biofuel (particularly, residential wood burning) emissions in the emissions inventory. Overall, the model evaluation highlights the importance of treating POA as semi-volatile and reactive in order to predict accurately the sources, composition and properties of ambient OA.

\section{Introduction}

Atmospheric aerosols play a key role in many ecological and environmental processes. They influence the earth's climate (IPCC, 2007) and have a large impact on public health (Bernstein et al., 2004). Organics account for a significant fraction of the fine atmospheric aerosol mass (Zhang et al., 2007) and hence have been extensively studied using climate models to determine their global impact (Penner et al., 1998; Cooke et al., 1999; Koch, 2001; Chung and Seinfeld, 2002; Park et al., 2003, 2006). However, when evaluated against observations, these models usually under-predict surface organic aerosol (OA) mass concentrations (Liousse et al., 1996;

Published by Copernicus Publications on behalf of the European Geosciences Union. 
Chung and Seinfeld, 2002; Park et al., 2003; Tsigaridis and Kanakidou, 2003; De Gouw et al., 2005; Heald et al., 2005; Volkamer et al., 2006). For example, Chung and Seinfeld (2002), on average, under-predicted organic carbon (OC) mass concentrations by a factor of 3 to 4 . Tsigaridis and Kanakidou (2003) observed a similar under-prediction over rural and marine areas where measured $\mathrm{OC}$ mass concentrations were lower than $1 \mu \mathrm{g} \mathrm{m}^{-3}$. Volkamer et al. (2006) noted that the discrepancy between model predicted secondary OA and observations increased with the photochemical age. Park et al. (2006), however, predicted OA concentrations within a factor of 2 with very little bias. This poor performance makes it difficult to evaluate the effects of OA on global climate and human health.

Previous quantitative evaluations of model performance have mainly focussed on absolute OA mass concentrations and not considered other properties such as chemical composition, volatility and isotopic composition. This has been due to the lack of field measurements and/or the limited prediction capabilities of models. Recently, instruments like the Aerosol Mass Spectrometer (AMS), Particle-Into-Liquid Sampler (PILS) and thermodenuders and techniques like radiocarbon isotope analysis have provided new insight into the sources, composition and reactivity of OA typically unavailable from mass measurements (Weber et al., 2001; Zhang et al., 2005; An et al., 2007; Schichtel et al., 2008). For example, global models tend to predict a dominance of primary organic aerosol (POA) or direct particulate emissions, which have been assumed to be non-volatile and non-reactive (Kanakidou et al., 2005; Jimenez et al., 2009). However, AMS results suggest that atmospheric OA is dominated by secondary organic aerosol or SOA which is aerosol mass formed from the oxidation products of gas-phase organic precursors (Robinson et al., 2007; Zhang et al., 2007). This is one example which points to potentially significant problems with how OA is simulated in global models.

The shortcomings in current OA models may partly be due to their assumption that POA is non-volatile and nonreactive. Recently, various studies have challenged these views (Robinson et al., 2007; Grieshop et al., 2009a,b; Huffman et al., 2009a). First, they showed that diesel engine, biomass burning and meat cooking POA emissions are semivolatile, i.e. they contained species that span a large range of vapor pressures that exist in a gas-particle equilibrium as dictated by absorptive partitioning theory (Pankow, 1994). Second, Robinson et al. (2007) argued that certain intermediate volatility organic compounds (IVOCs), capable of forming $\mathrm{OA}$, were missing from emission inventories compiled using conventional techniques. Using source test data, Shrivastava et al. (2008) estimated the missing IVOCs to account for 0.25 to 2.8 times the POA mass measured using conventional filter techniques. Third, smog chamber experiments demonstrated that photooxidation of diesel exhaust and woodsmoke enhanced OA concentrations beyond that predicted by the oxidation of conventional VOC precursors (Robinson et al.,
2007; Sage et al., 2008; Grieshop et al., 2009b; Miracolo et al., 2010). It is suspected that semi-volatile and IVOC vapors oxidize to generate additional SOA; this SOA has been recently termed non-traditional SOA (Donahue et al., 2009).

On a regional scale, recent efforts in modeling carbonaceous aerosols have considered the semi-volatile and reactive nature of POA (Robinson et al., 2007; Shrivastava et al., 2008; Murphy and Pandis, 2009). The only study, so far, to have attempted that in a global model is that by Pye and Seinfeld (2010). All of these new models predict a global dominance of SOA and bring the POA/SOA split in better agreement with field measurements. Although they arrive at similar qualitative conclusions, the schemes used to model semi-volatile and reactive POA are not well constrained due to the lack of available experimental data and are therefore very uncertain. In light of this uncertainty, an important next step is to assess these schemes by evaluating model performance in direct comparison with observations.

In this paper, we model semi-volatile and reactive POA and IVOC emissions using the volatility basis set (VBS) in conjunction with a global climate model. The VBS is an efficient framework for simulating the gas-particle partitioning, dilution and chemical aging of semi-volatile organics. Model performance is evaluated using observations of surface mass concentration, oxygenation, volatility and isotopic composition.

\section{Model description}

In this work, we use a "unified" general circulation model (GCM) to simulate global OA. The model is based on the Goddard Institute for Space Studies General Circulation Model II' (GISS GCM II') (Hansen et al., 1983; Rind and Lerner, 1996; Rind et al., 1999) and includes online tropospheric chemistry (Harvard tropospheric $\mathrm{O}_{3}-\mathrm{NO}_{\mathrm{x}}-$ hydrocarbon chemical model Liao et al., 2003) and aerosol modules (Adams et al., 1999; Chung and Seinfeld, 2002; Liao et al., 2004; Farina et al., 2010). The GCM has a horizontal resolution of $4^{\circ}$ latitude by $5^{\circ}$ longitude with 9 vertical layers. The simulated period represents a non-specific year near the beginning of the 21 st century. In addition to organics and elemental carbon (soot), the GCM explicitly treats sulfate, nitrate, ammonium, sea salt and mineral dust as described in Liao and Seinfeld (2005).

The OA model is based on the work of Farina et al. (2010). Farina et al. (2010) implemented the VBS to simulate the formation and gas-particle partitioning of SOA produced from the oxidation of VOC precursors (isoprene, monoterpenes, sesquiterpenes, alkanes, alkenes and aromatics). In addition, they also used the VBS to model the gas-phase aging of anthropogenic SOA. They assumed that POA was nonvolatile and non-reactive and also did not account for IVOCs. In this paper we modified the model of Farina et al. (2010) to account explicitly for semi-volatile and reactive POA and 


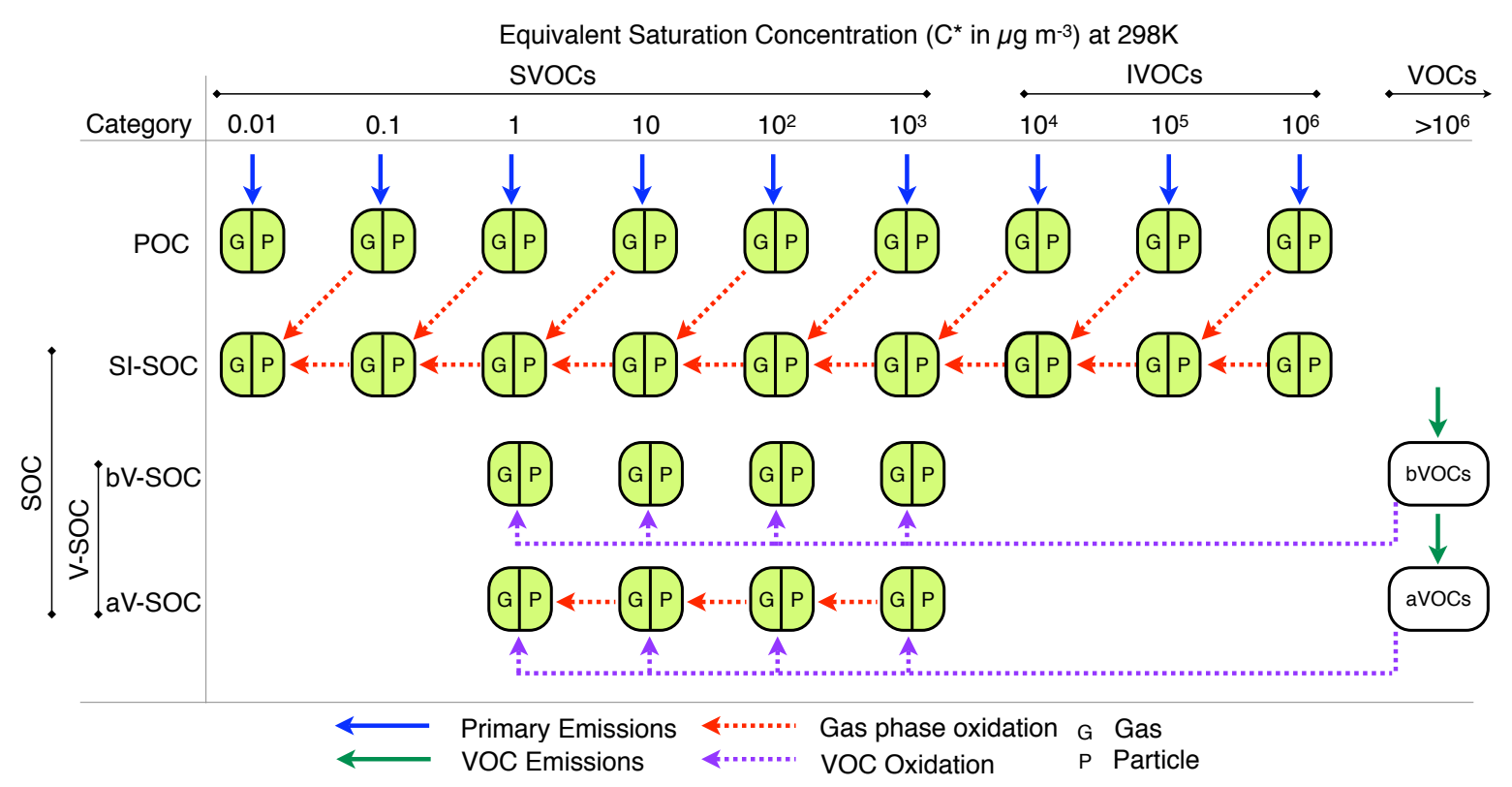

Fig. 1. Schematic for the volatility basis set (VBS) framework as used in this study. The saturation concentration spectrum is divided into semi-volatile (SVOC, $C^{*}=0.01-10^{3} \mu \mathrm{g} \mathrm{m}^{-3}$ ) and intermediate volatility (IVOC, $C^{*}=10^{4}-10^{6} \mu \mathrm{g} \mathrm{m}^{-3}$ ) organic compounds. VOCs are graphically presented with $C^{*}>10^{6}$. bVOCs and aVOCs are biogenic and anthropogenic VOCs respectively. See Sects. 2.1.1 and 2.1.2 for a detailed discussion.

IVOCs. We use the VBS to describe their emissions, mixing, gas-particle partitioning and aging. The ensuing sections describe in detail the revised OA model.

\subsection{Organic Aerosol (OA) modeling}

\subsubsection{Volatility basis set and equilibrium partitioning}

The VBS framework describes OA by separating low volatility organics into decadally spaced bins of effective saturation concentration $\left(C^{*}\right)$ between 0.01 to $10^{6} \mu \mathrm{g} \mathrm{m}^{-3}$ (Fig. 1) (Donahue et al., 2006). $C^{*}$ (inverse of the Pankow-type partitioning coefficient, $K_{\mathrm{p}}$ ) is proportional to the saturation vapor pressure and is a semi-empirical property that describes the gas-particle partitioning of an organic mixture (Pankow, 1994). Each $C^{*}$ "bin" contains species that span a range of volatilities, i.e. the $1 \mu \mathrm{g} \mathrm{m}^{-3}$ bin contains species with $C^{*}$ between $0.3 \mu \mathrm{g} \mathrm{m}^{-3}$ and $3 \mu \mathrm{g} \mathrm{m}^{-3}$. The lowest volatility bin, $0.01 \mu \mathrm{g} \mathrm{m}^{-3}$, contains all species lower in volatility than $0.03 \mu \mathrm{g} \mathrm{m}^{-3}$. The $C^{*}$ spectrum is conventionally divided into semi-volatile (SVOC, $0.01-10^{3} \mu \mathrm{g} \mathrm{m}^{-3}$ ) and intermediate volatility (IVOC, $10^{4}-10^{6} \mu \mathrm{g} \mathrm{m}^{-3}$ ) organic compounds.

Unlike previous models, the revised model explicitly treats the gas-particle partitioning of all low volatility organics. The model assumes ambient OA to exist in an equilibrium between the gas and particle phases as dictated by Raoult's law and that the organics in the particle phase form a pseudoideal solution (Pankow, 1994). The partitioning equations are as follows (Donahue et al., 2006):

$$
\zeta_{i}=\left(1+\frac{C_{i}^{*}}{C_{\mathrm{OA}}}\right)^{-1} ; \quad C_{\mathrm{OA}}=\sum_{i=1}^{N} \zeta_{i} \times \mathrm{OC}_{i}
$$

where $\zeta_{i}$ is the fraction of organic mass in volatility bin $i$ in the particulate phase, $C_{i}^{*}$ is the effective saturation concentration of bin $i$ in $\mu \mathrm{g} \mathrm{m}^{-3}, C_{\mathrm{OA}}$ is the total particulate $\mathrm{OA}$ $(\mathrm{POA}+\mathrm{SOA})$ concentration in $\mu \mathrm{g} \mathrm{m}^{-3}, \mathrm{OC}_{i}$ is the total organic concentration (gas + particle) in bin $i$ in $\mu \mathrm{g} \mathrm{m}^{-3}$ and $N$ is the number of basis set bins. An important uncertainty is whether all components of OA absorb into the same phase as this would affect the value of $C_{\mathrm{OA}}$. Recent experimental evidence on this issue are mixed where some studies indicate a single phase (Asa-Awuku et al., 2009) while others indicate multiple phases (Song et al., 2007). In the absence of conclusive evidence that suggests phase separation for ambient $\mathrm{OA}$, we assume all OA (POA and SOA) to form a single phase. In addition, Shrivastava et al. (2008) found that multiple phases had a very small effect on predicted OA mass concentrations in simulations that treated POA as semi-volatile and reactive.

Shifts in gas-particle partitioning due to changes in temperature are represented using the Clausius-Clapeyron equation (Donahue et al., 2006),

$C_{i}^{*}(T)=C_{i}^{*}\left(T_{\text {ref }}\right) \exp \left[\frac{\Delta H_{\mathrm{v}}}{R}\left(\frac{1}{T_{\text {ref }}}-\frac{1}{T}\right)\right] \frac{T_{\text {ref }}}{T}$

where $T_{\text {ref }}$ is the reference temperature $(298 \mathrm{~K}), \Delta H_{\mathrm{v}}$ is the enthalpy of vaporization and $R$ is the universal gas constant. $\Delta H_{\text {vap }}$ is an uncertain parameter and therefore simulations are performed to assess the sensitivity of the results to a varying $\Delta H_{\text {vap }}$. 


\subsubsection{OA terminology}

OA has been traditionally divided into two categories: POA and SOA. POA is organic material directly emitted in the particle phase; it has traditionally been assumed to be nonvolatile and non-reactive. SOA is OA formed in the atmosphere from reactions of gaseous precursors; traditional chemical transport models have only accounted for SOA production from very volatile precursors. However, recent research has blurred the distinction between POA and SOA. Hence, it is necessary to revise certain conventionally used terms that are now either obsolete and/or confusing.

Figure 2 represents the various classes of OA with the help of a tree diagram. Using the VBS framework, we define primary organic carbon (POC) as the sum of all the emissions that have a $C^{*}$ lower than $10^{6} \mu \mathrm{g} \mathrm{m}^{-3}$. This includes all traditionally defined POA emissions and any IVOC emissions added to the model. We assume that organic emissions with $C^{*}$ higher than $10^{6} \mu \mathrm{g} \mathrm{m}^{-3}$ are explicitly accounted as VOC species. As POC is semi-volatile, it dynamically partitions between the gas and particle phases with changes in dilution and temperature. We define POA as the particle phase component of POC and primary organic gas (POG) as the vapor phase component of POC. We further categorize POC into SVOCs and IVOCs, where SVOCs refer to the gas + particle organic mass in the 0.01 to $1000 \mu \mathrm{g} \mathrm{m}^{-3}$ bins and IVOCs refer to the organic mass in the $10^{4}$ to $10^{6} \mu \mathrm{g} \mathrm{m}^{-3}$ bins. The exact boundary between the SVOCs and IVOCs is somewhat artificial; SVOCs exist in both the gas and particle phase while IVOCs exist exclusively as vapors in the atmosphere but are less volatile than VOCs. This distinction is made to examine the influence of IVOCs on the OA budget, an influence that has been explored by only a handful of studies (Shrivastava et al., 2008; Murphy and Pandis, 2009; Farina et al., 2010; Pye and Seinfeld, 2010).

A key objective of this work is to study the fate of SVOC and IVOC vapors which are believed to oxidize in the atmosphere to form lower volatility products, which condense into the particle phase. In this work, we use terminology used in Tsimpidi et al. (2009) and define S-SOG and S-SOA as the gas and particle phase components arising from the oxidation of SVOC vapors. Similarly, we define I-SOG and I-SOA as the gas and particle phase components arising from the oxidation of IVOC vapors. SI-SOG is the sum of S-SOG and I-SOG and SI-SOA is the sum of S-SOA and I-SOA. The sum of SI-SOG and SI-SOA is called SI-SOC.

Gas and particle phase products from the oxidation of VOCs are referred as V-SOG and V-SOA respectively, with their sum defined as V-SOC. The traditional abbreviations are prefixed with " $a$ " to identify the anthropogenic contribution and " $b$ " for the biogenic contribution. OA, hence, is a sum of POA, SI-SOA and V-SOA while SOA is the sum of SI-SOA and V-SOA.

This VBS framework can efficiently track material from any number of different sources and precursors. However,

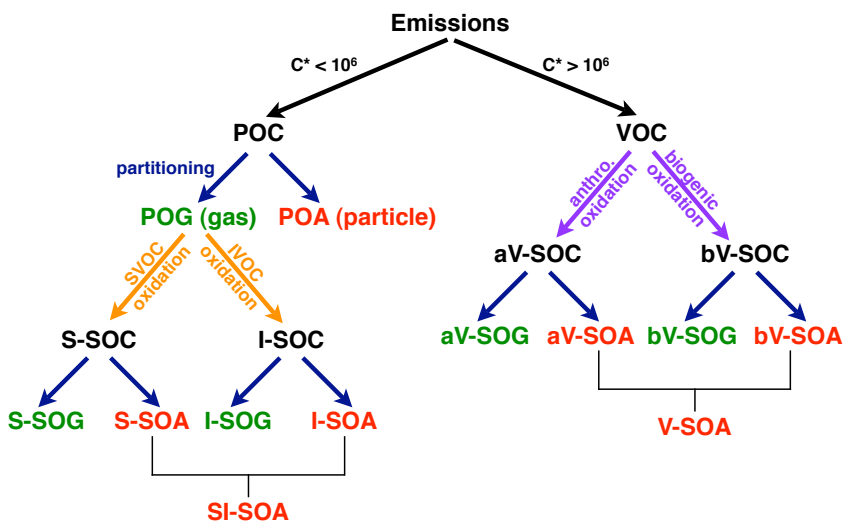

Fig. 2. Tree diagram of various classes of OA in the revised model.

given the computational resources available and the goals of the paper, the model separately tracks four classes of organics as shown in Fig. 1: POC, SI-SOC (S-SOC and I-SOC together), aV-SOC and bV-SOC. POC and SI-SOC are tracked using two separate 9 bin VBS while bV-SOC and aV-SOC are tracked using two separate 4 bin VBS (Fig. 1). The VOC precursors for V-SOC shown in Fig. 1 are described in detail in Farina et al. (2010).

Other recent papers have also proposed new definitions for different classes of OA. To help the reader, Table 1 relates the different types of OA referred to in this paper to those used in recent manuscripts that deal with semi-volatile POC and SOC.

\subsubsection{POC emissions}

To simulate POC, we need to the know the total emissions of low volatility $\left(C^{*}<10^{6} \mu \mathrm{g} \mathrm{m}^{-3}\right)$ organics and their volatility distribution. However, this information is only known for a very small number of sources. Therefore, we estimate the POC emissions using existing inventories and data from studies of diesel exhaust and woodsmoke to distribute these emissions in volatility space.

Table 2 lists the annual global emissions of POC and elemental carbon (EC) by source category. The POC emissions are the sum of the traditional POA emissions from existing inventories plus an estimate of the missing IVOC emissions. The combined inventory, representative of emissions for the early 21 st century, provides a monthly averaged value for each grid cell.

Traditional particulate matter emission inventories are compiled using emission factors that are determined using quartz and/or teflon filters collected at elevated aerosol concentrations (100-10000 $\mathrm{g} \mathrm{m}^{-3}$ ). Hence, these inventories do not capture all of the POC emissions up to $C^{*}=$ $10^{6} \mu \mathrm{g} \mathrm{m}^{-3}$ (Shrivastava et al., 2008; Robinson et al., 2010). Shrivastava et al. (2008) assumed that traditional emission inventories account for all SVOC emissions but only a fraction of the IVOC emissions. Source test data suggest that 
Table 1. Definitions and abbreviations used for classes of OA.

\begin{tabular}{|c|c|c|c|c|c|}
\hline \multirow[b]{2}{*}{ Categories } & \multicolumn{5}{|c|}{ Publication } \\
\hline & $\begin{array}{l}\text { This work/ } \\
\text { Tsimpidi et al. (2009) }\end{array}$ & $\begin{array}{l}\text { Shrivastava } \\
(2008)\end{array}$ & $\begin{array}{l}\text { Murphy and Pandis } \\
\text { (2009) }\end{array}$ & $\begin{array}{l}\text { Dzepina et al. } \\
(2009)\end{array}$ & $\begin{array}{l}\text { Dzepina et al. } \\
(2010)\end{array}$ \\
\hline $\begin{array}{l}\text { Unoxidized POA } \\
\text { or fresh POA }\end{array}$ & POA & POA & FPOA & POA & POA \\
\hline $\begin{array}{l}\text { SOA from SVOCs } \\
\text { and IVOCs or non- } \\
\text { traditional SOA }\end{array}$ & $\begin{array}{l}\mathrm{S}-\mathrm{SOA}+ \\
\mathrm{I}-\mathrm{SOA}= \\
\text { SI-SOA }\end{array}$ & OPOA & OPOA & NT-SOA & $\begin{array}{l}\text { SOA }_{S V O C} \\
+ \text { SOA IVOC }^{\text {IVOC }}\end{array}$ \\
\hline $\begin{array}{l}\text { Biogenic and an- } \\
\text { thropogenic SOA } \\
\text { from VOCs or traditional SOA }\end{array}$ & $\begin{array}{l}\text { bV-SOA, } \\
\text { aV-SOA }\end{array}$ & $\begin{array}{l}\text { Biogenic SOA, } \\
\text { Anthro. SOA }\end{array}$ & $\begin{array}{l}\text { BSOA, } \\
\text { ASOA }\end{array}$ & T-SOA & $\begin{array}{l}\text { Traditional } \\
\text { SOA }\end{array}$ \\
\hline
\end{tabular}

Table 2. Annual emissions of POC and elemental carbon (EC) by source category.

\begin{tabular}{|c|c|c|}
\hline & \multicolumn{2}{|c|}{ Annual Emissions $\left(\mathrm{Tg} \mathrm{yr}^{-1}\right)$} \\
\hline Source & $\mathrm{POC}^{\mathrm{a}}$ & $\mathrm{EC}$ \\
\hline \multicolumn{3}{|l|}{ Fossil Fuels } \\
\hline North America (Heald) ${ }^{b}$ & 1.14 & 1.35 \\
\hline North America (Bond) ${ }^{\mathrm{c}}$ & 0.66 & 0.42 \\
\hline Rest of the world (Bond) ${ }^{\mathrm{c}}$ & 3.67 & 2.62 \\
\hline \multicolumn{3}{|l|}{ Bio Fuels } \\
\hline North America (Heald) ${ }^{b}$ & 2.04 & 0.19 \\
\hline North America (Bond) ${ }^{\mathrm{c}}$ & 0.98 & 0.10 \\
\hline Rest of the world (Bond) ${ }^{c}$ & 10.7 & 1.52 \\
\hline Open Burning (GFEDv2) ${ }^{\mathrm{d}}$ & 38.9 & 2.74 \\
\hline Total (Heald + Bond + GFEDv2) & 56.4 & 8.42 \\
\hline Total (Bond + GFEDv2) & 54.9 & 7.40 \\
\hline
\end{tabular}

a Assuming an OM:OC of $1.8,{ }^{\mathrm{b}}$ Heald et al. (2005), ${ }^{\mathrm{c}}$ Bond et al. (2004), ${ }^{\mathrm{d}}$ Van der Werf et al. (2006).

the amount of IVOC emissions missing is between 0.25 and 2.8 times the POC emissions measured using a quartz filter (Schauer et al., 1999, 2001, 2002).

For this work, we used the traditional fossil and biofuel POA emissions from Bond et al. (2004), which are not based on a specific year. The open burning emissions are based on GFEDv2 (Van der Werf et al., 2006); they are from 2005 as the annual emissions for that year lie close to the median for the 1997 through 2006 period. Although the Bond et al. (2004) inventory is the most recent for fossil and biofuel combustion emissions, the North American winter-time predictions based on this inventory are a factor of 2 too low when compared to observations (Heald et al., 2006b). Therefore, we updated the Bond et al. (2004) North American traditional POA and EC emissions using the Cooke et al. (1999) fossil fuel inventory and the Park et al. (2003) biofuel inventory (Heald et al., 2005). We use an organic-matterto-organic-carbon ratio of 1.8 to convert the POC emission inventory values from $\mathrm{TgC} \mathrm{yr}^{-1}$ to $\mathrm{Tg} \mathrm{yr}^{-1}$ (Turpin and Lim, 2001; El-Zanan et al., 2005; Zhang et al., 2005).

Following the approach of Shrivastava et al. (2008), we assume the SVOC emissions to be completely represented by the traditional emission inventory or $56.4 \mathrm{Tg} \mathrm{yr}^{-1}$ and that the IVOC emissions are 1.5 times the traditional emission inventory or $84.6 \mathrm{Tg} \mathrm{yr}^{-1}$.

Pye and Seinfeld (2010) used a different approach to estimate the missing IVOC emissions. They use naphthalene as a surrogate and estimate IVOC emissions to be $27 \mathrm{Tg}$ $\mathrm{yr}^{-1}$ which is close to the lower end of the range suggested by the source test data. Given the large uncertainty, simulations are performed to investigate the sensitivity of the predictions to the amount of IVOC emissions.

The revised model requires that the POC emissions be distributed across the VBS. This requires knowing the volatility distribution of the emissions. In this work, we assume that all POC emission sources (fossil fuels, biofuels, open burning) have the same volatility distribution as there are currently inadequate data to perform a more refined analysis (Robinson et al., 2007). This volatility distribution is the same as that determined for diesel exhaust (Robinson et al., 2007) and used by Shrivastava et al. (2008) to predict the evolution of OA in the eastern US. In reality, the emissions from each source have a distinct composition of organic species and therefore a unique volatility distribution. However, volatility data are available for very few sources (Robinson et al., 2007; Grieshop et al., 2009a). To address potential uncertainty associated with our assumption we conducted different model simulations using different volatility distributions.

\subsubsection{Photochemical aging}

Organic vapors react with atmospheric oxidants which change their volatility, gas-particle phase partitioning and hence the amount of OA. This process, within the bounds 
of the VBS, is termed aging. Here, aging does not include the oxidation of VOCs, which is dealt with explicitly in other parts of the model. In this paper, aging also does not include the microphysical processes (condensation and coagulation) that produce an internally mixed aerosol. Finally, the model also does not account for any aging due to heterogeneous, aqueous phase and condensed-phase reactions. We recognize that these processes might be important but given the uncertainty, we choose to focus on the gas phase aging of organic vapors.

We use a simple aging mechanism as used in previous studies employing the VBS (Lane et al., 2008; Shrivastava et al., 2008; Farina et al., 2010). The basic scheme is illustrated using red arrows in Fig. 1. Aging proceeds by a firstorder reaction of VBS vapors with $\mathrm{OH}$ radicals producing a product that has a $C^{*}$ one order of magnitude lower than its precursor. The vapor concentration after time $\Delta t$ is given in Eq. (3) where $\mathrm{OG}_{i}^{t}$ represents the mass of gas-phase organics in bin $i$ at time $t,[\mathrm{OH}]$ is the $\mathrm{OH}$ radical concentration and $k_{\mathrm{OH}}$ is the reaction rate constant.

$$
\begin{aligned}
\mathrm{OG}_{i}^{t+\Delta t} & =\mathrm{OG}_{i}^{t} \exp \left(-k_{\mathrm{OH}}[\mathrm{OH}] \Delta t\right) \\
& +\mathrm{OG}_{i+1}^{t}\left[1-\exp \left(-k_{\mathrm{OH}}[\mathrm{OH}] \Delta t\right)\right]
\end{aligned}
$$

We assume that the oxidation products in the vapor phase continue to age and form even lower volatility products. Although oxidation might result in additional mass being added to the products, we are conservative in our aging scheme and do not add any additional mass. Primary organic vapors or POG and SI-SOG are assumed to age with a reaction rate of $4 \times 10^{-11} \mathrm{~cm}^{3}$ molecules ${ }^{-1} \mathrm{~s}^{-1}$, based on the work of Shrivastava et al. (2008).

The aging mechanism used in this work is very different from that of Pye and Seinfeld (2010). They model SVOC aging using a single oxidation step that adds $50 \%$ additional mass and assign the aged products a $C^{*}$ value two orders of magnitude lower than the precursors. They model IVOC oxidation by assuming that the SOA forming potential of IVOCs is the same as naphthalene. Therefore, a fundamental difference is that Pye and Seinfeld (2010) assume that the aging process can be captured in a single oxidation step and hence they have a specific $C^{*}$ for their aged products. Our mechanism, in contrast, implicitly assumes that the gas phase aged products continue to oxidize to form products that steadily move down in $C^{*}$ space. In addition, our lowest VBS $C^{*}$ bin $\left(0.01 \mu \mathrm{g} \mathrm{m}^{-3}\right)$ is much lower than most of the $C^{*}$ s used by Pye and Seinfeld (2010) to represent their aged products $(0.2$ and $16.46 \mu \mathrm{g} \mathrm{m}^{-3}$ for SVOCs and 0.0001 and $1.69 \mu \mathrm{g} \mathrm{m} \mathrm{m}^{-3}$ for IVOCs). Therefore, given time, our aging scheme will tend to form more OA than Pye and Seinfeld (2010) though it is difficult to say which is correct based on available data. Although we know very little about how aging proceeds, we believe it has a large influence on the OA budget and the ability of the model to reproduce observations. To illustrate its influence, we run a simulation where the POC is treated as semi-volatile but not allowed to age.
Farina et al. (2010) assumed that the SOA mass yields for biogenic VOCs represent completed reactions and hence they do not need to be aged. We realize that this is a significant assumption that requires additional study that is outside the scope of this manuscript. However, simple "first guess" aging parameterizations, when applied to biogenic SOA, lead to gross over-predictions in regional models (Lane et al., 2008; Murphy and Pandis, 2009). Hence, as per Farina et al. (2010), the biogenic V-SOG is not allowed to age while the anthropogenic V-SOG is allowed to age with a reaction rate of $4 \times 10^{-11} \mathrm{~cm}^{3}$ molecules ${ }^{-1} \mathrm{~s}^{-1}$.

Previous studies that have modeled POA as non-volatile have considered a hydrophobic to hydrophilic conversion of POA, which has been referred to as "aging" without being very precise about what processes were being represented. Although, it was initially meant to represent the evolution of POA from an externally mixed to an internally mixed state (Cooke et al., 1999), it has also been interpreted to represent a heterogeneous oxidation of OA to more hydrophilic products. In either case, aging in traditional models is different than aging here, which is defined as ongoing oxidation of organics in the vapor phase. Moreover, we argue, based on the arguments by Kroll et al. (2011), that heterogenous chemistry appears to be a much slower process than the photochemical aging described in this section.

\subsubsection{Deposition}

Gas and particle phase organics are subject to dry and wet deposition. Dry deposition of gas-phase organics is based on the resistance-in-series scheme of Wesley (1989). Particlephase dry deposition velocities are calculated based on the treatment of sulfate as described in Koch et al. (1999). Wet deposition of gas and particle phase organics are treated separately for large-scale and convective clouds, following the GCM cloud schemes described in Del Genio and Yao (1993) and Del Genio et al. (1996). Dissolved gases and aerosols are scavenged within and below precipitating clouds. The solubility of gases is defined by their Henry's law constant and all organic gases are assigned a Henry's law constant of $10^{5} \mathrm{M} \mathrm{atm}^{-1}$. It is likely that higher volatility products on account of being less oxygenated have a lower Henry's law constant and vice-versa but in the absence of any robust data, we consider it to be constant across volatility. Also, we do not perform a sensitivity simulation with the Henry's law constant because the effect was previously explored by Farina et al. (2010).

The previous version of the unified model (Farina et al., 2010) divided POA into hydrophobic and hydrophilic categories which had different wet deposition characteristics (Chung and Seinfeld, 2002). By assuming that OA forms a single phase (Sect. 2.1.1), we use the same wet deposition characteristics for all OA and hence avoid this additional categorization all together. Following Chung and Seinfeld (2002), all organic particles are assigned a scavenging 

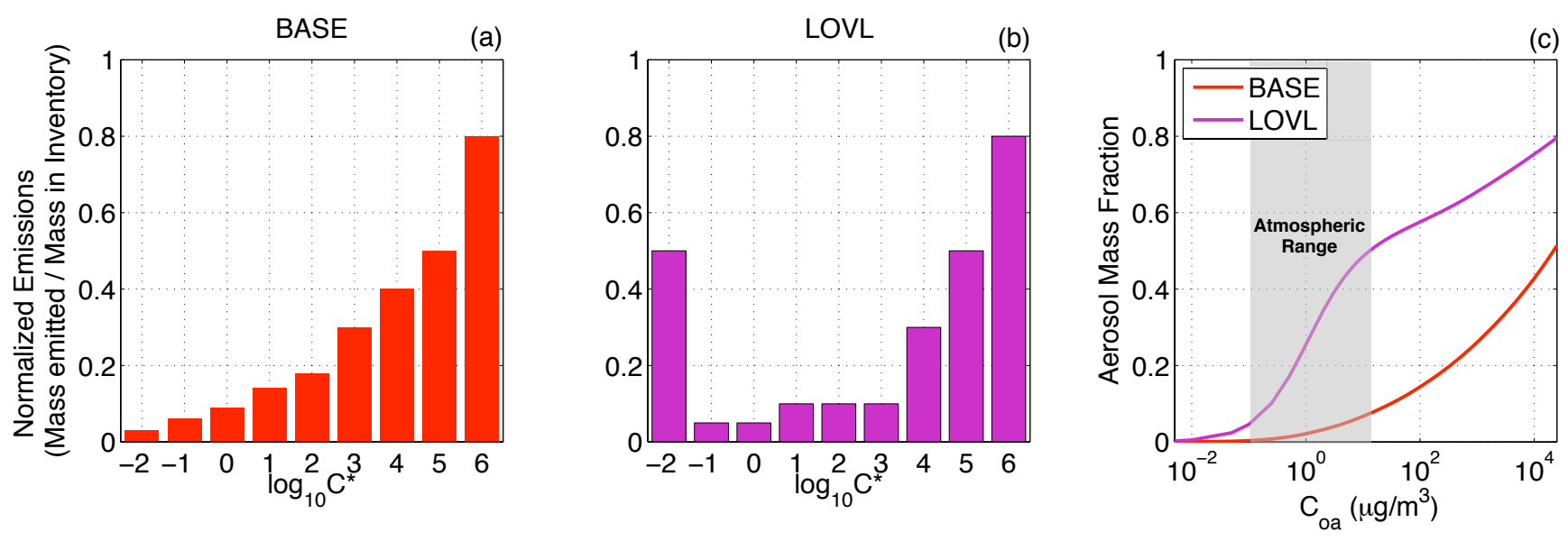

Fig. 3. Volatility distribution of POC emissions for (a) BASE and (b) LOVL scenarios as a fraction normalized to the traditional POC emission inventory total. Panel (c) shows the change in aerosol mass fraction for the BASE and LOVL volatility distributions as a function of $C_{\mathrm{OA}}$ at $298 \mathrm{~K}$. The normalized SVOC emissions fully represent the traditional POC emission inventory and hence sum to 1 . The normalized IVOC emissions are 1.5 times the emission inventory and hence sum to 1.5 .

efficiency of $80 \%$. Again, it is likely that the scavenging efficiency, just like the Henry's law constant, is a function of volatility but in the absence of any robust data, we consider it to be constant across volatility.

\section{Simulations}

Multiple simulations were performed to evaluate the performance of the new modeling framework. Each simulation was performed for a one-year period with four months of spin up time to initialize concentration fields. Given the uncertainty in many input variables, we have evaluated the sensitivity of model results to the POC emissions, POC volatility distribution, IVOC emissions, partitioning process and photochemical aging. The sensitivity scenarios run in this study are listed in Table 3 and briefly described below.

- BASE: This simulation represents our best estimate for all the input parameters. As described previously, fossil and bio fuel emissions of POC are from Heald et al. (2006a) for North America and Bond et al. (2004) for the rest of the world and open burning emissions are from GFEDv2 (Van der Werf et al., 2006). All POC sources (fossil fuel, bio fuel, open burning) are treated alike and have the same volatility distribution, as shown in Fig. 3a. IVOC emissions are assumed to be 1.5 times the published POC emissions. To represent the dependence of $C_{\mathrm{OA}}$ on temperature, we use a $\Delta H_{\mathrm{v}}$ value of $30 \mathrm{~kJ} \mathrm{~mole}^{-1}$, a value that has been used by Farina et al. (2010).

- TRAD (TRADitional): To compare and quantify the progress made in this research effort, the model is also run in the traditional configuration where we treat POC as non-volatile and non-reactive. This is the same version of the model that Farina et al. (2010) ran except for changes in the POC emission inventory.

- LOEM (LOw EMissions): To investigate the sensitivity of the model to the magnitude of the POC emissions, we run the LOEM scenario that utilizes the Bond et al. (2004) inventory over North America. This reduces the fossil and bio fuel POC emissions over North America by slightly less than $50 \%$.

- LOVL (LOw VoLatility): To investigate the sensitivity of the model to the volatility distribution of the POC emissions, we employ a low volatility distribution which is constructed by moving half of the mass in the SVOC bins to the lowest bin without altering the IVOC distribution. Figure $3 b$ plots the LOVL volatility distribution.

- NOIV (NO IVOC's): To quantify the contribution of IVOCs to global OA, we run the NOIV (NO IVOC's) scenario where no IVOCs are added to the inventory.

- HVAP (Heat of VAPorization): To quantify the sensitivity of the results to the enthalpy of vaporization, we use the work of Epstein et al. (2010) to describe $\Delta H_{\mathrm{vap}}$ as a function of $C^{*}$ and temperature. Epstein et al. (2010) propose a much larger range of $\Delta H_{\text {vap's }}$ 's $\left(40-150 \mathrm{~kJ} \mathrm{~mole}^{-1}\right)$ than used in the BASE case. One needs to exercise caution when interpreting results from the HVAP scenario as yields for SOA formation have been derived using a single value for the heat of vaporization $\left(\Delta H_{\mathrm{vap}}=30-60 \mathrm{~kJ}\right.$ mole ${ }^{-1}$ depending on the study). However, given that most SOA chamber experiments are done quite close to $298 \mathrm{~K}$ - the reference 
Table 3. Overview of simulations.

\begin{tabular}{llllll}
\hline Framework & Name & POA & Aging? & US Inventory & Compared to BASE \\
\hline Traditional & TRAD & Non-volatile & No & Heald & Non-volatile and non-reactive POA \\
\hline \multirow{6}{*}{ Revised } & BASE & Semi-volatile & Yes & Heald & - \\
& LOEM & Semi-volatile & Yes & Bond & Lower emissions in North America \\
& LOVL & Semi-volatile & Yes & Heald & Lower volatility POC \\
& NOIV & Semi-volatile & Yes & Heald & No IVOCs \\
& HVAP & Semi-volatile & Yes & Heald & $\Delta H_{\text {vap as a function of } C^{*} \text { and } T}$ \\
& NOAG & Semi-volatile & No & Heald & No POC Aging \\
\hline
\end{tabular}
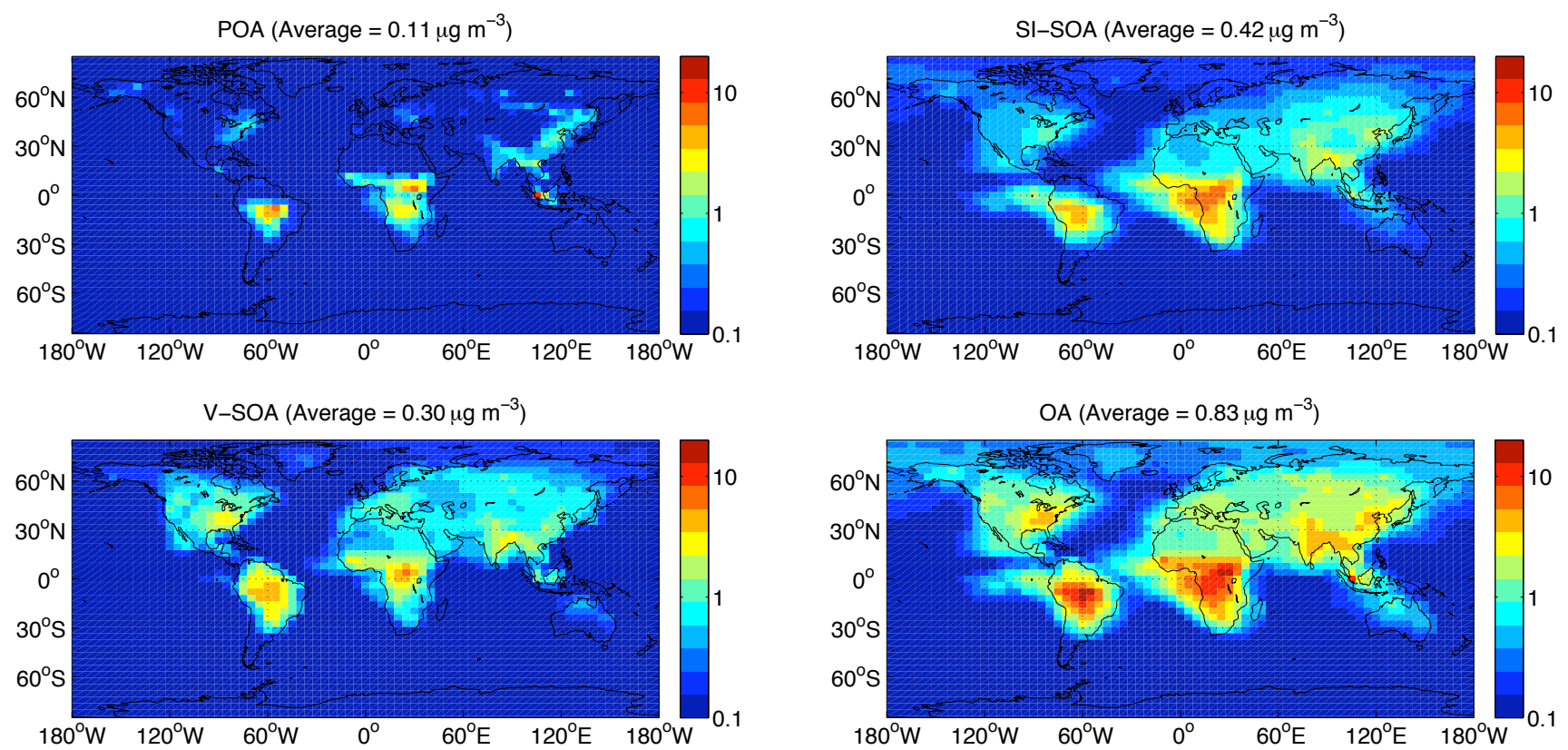

Fig. 4. Annual-average surface mass concentrations of POA, SI-SOA, V-SOA and total OA in $\mu \mathrm{g} \mathrm{m}^{-3}$ for BASE simulation. Area-weighted surface concentrations are shown in parentheses.

temperature for the VBS - using the revised heat of vaporization values will not have a large effect on the SOA mass yields.

- NOAG (NO AGing): To investigate the influence of gas-phase POC aging on OA burdens, we run the NOAG scenario where POC is treated as semi-volatile but the vapors are not allowed to age to form SI-SOA.

\section{Results}

\subsection{Model predictions}

\subsubsection{Surface concentrations}

Figure 4 plots the annually-averaged global surface mass concentration for POA, SI-SOA, V-SOA and total OA predicted using the BASE model. Their domain-averaged surface mass concentrations are $0.11,0.42,0.30$ and $0.83 \mu \mathrm{g} \mathrm{m}^{-3}$, respectively. The highest OA mass concentrations are predicted in the Amazon, Congo and southeast Asian tropical forests. They are due to a combination of biomass burning emissions and SOA formed from biogenic VOCs. Higher OA mass concentrations are also predicted in the northeastern US and parts of India and China where there are substantial fossil and biofuel combustion emissions.

Appreciable amounts of POA are only present in locations where total OA mass concentrations are high $\left(>5 \mu \mathrm{g} \mathrm{m}^{-3}\right)$, i.e. close to locations with high emissions. However, over most of the modeling domain, OA mass concentrations are low $\left(<5 \mu \mathrm{g} \mathrm{m}^{-3}\right)$ and most $(97 \%)$ of the POC evaporates leaving very little directly-emitted organic mass in the particle phase. Therefore, the POA concentrations in the revised model are spatially inhomogeneous. In contrast, the spatial distribution of SI-SOA, which is formed from POC vapors, is more homogenous and exhibits a well-mixed regional 


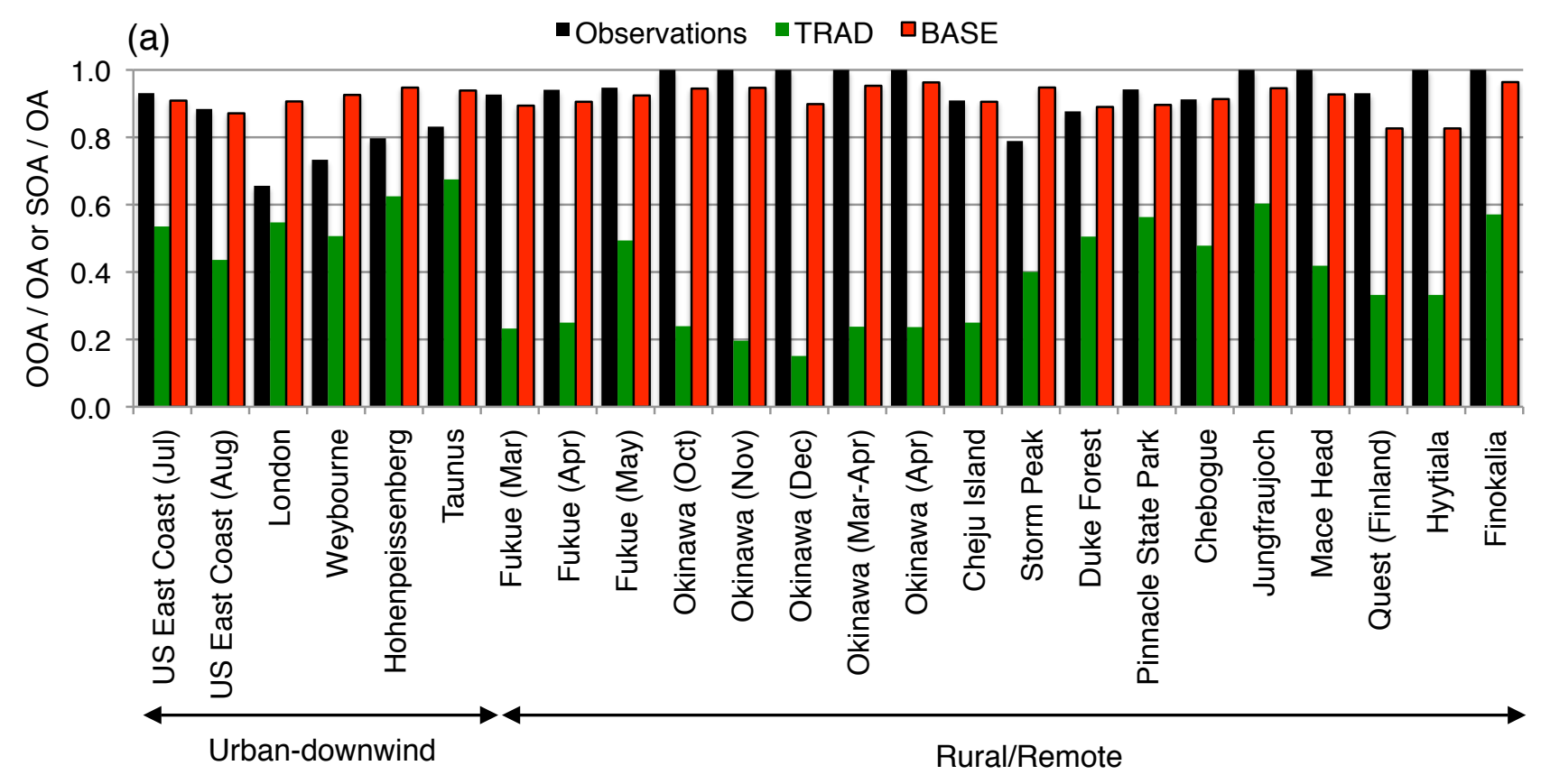

(b)

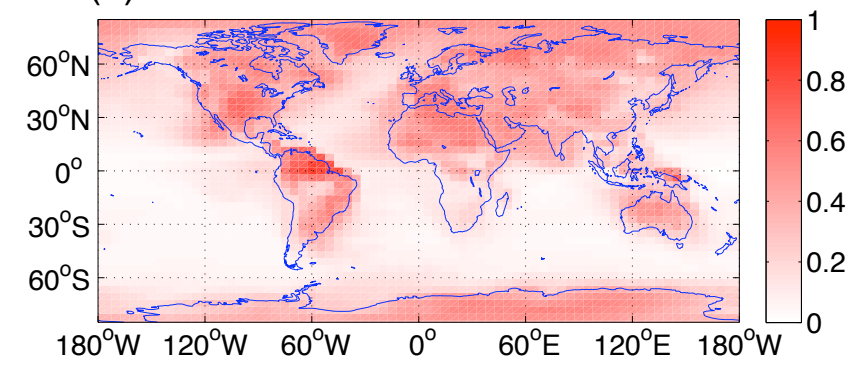

(c)

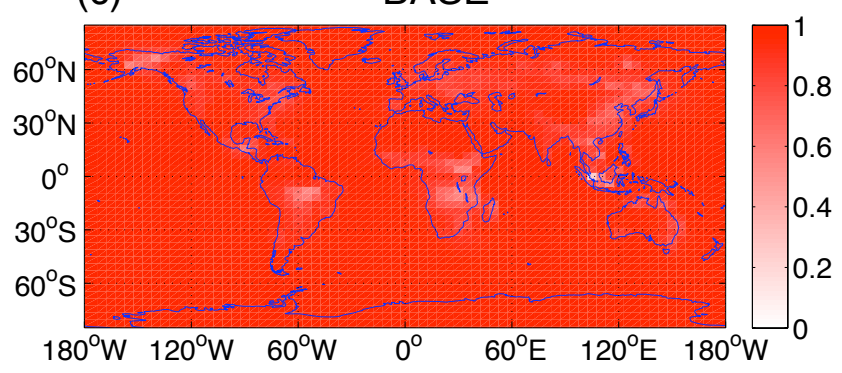

Fig. 5. (a) Comparison of observed OOA to OA ratios with model results of SOA to OA ratios from the BASE and TRAD scenarios. Model-predicted global distribution of SOA to OA ratio for (b) TRAD and (c) BASE cases. Data in (a) are from Zhang et al. (2007).

presence. In fact, SI-SOA, although derived from POC emissions, resembles traditional SOA or V-SOA in terms of its spatial distribution.

In contrast to most previous models, the BASE model predicts a global distribution of OA that is dominated by SOA. To illustrate this, Fig. 5b-c plots the model-predicted global distribution of the SOA-to-OA ratio using annually-averaged values for the TRAD and BASE scenarios. The BASE model consistently predicts a SOA-to-OA ratio of 0.8 or higher for all locations except for the Amazon, Congo, Alaska and east coast of China. In the TRAD case, OA in most locations is predicted to be POA. For example, over land the SOAto-OA ratio ranges from 0.4 to 0.7 while over oceans the ratio is close to 0.1 . Therefore, the TRAD case predicts a higher SOA fraction near source regions and a lower SOA fraction away from source regions, a trend that is reversed in the BASE case.

\subsubsection{OA budgets}

Figure 6 presents the breakdown of the overall OA budget. POC emissions, directly and indirectly via chemistry, contribute $57.5 \mathrm{Tg} \mathrm{yr}^{-1}$ of OA and traditional VOC oxidation forms $33.1 \mathrm{Tg} \mathrm{yr}^{-1}$ of $\mathrm{OA}$ to yield a total OA production rate of $90.6 \mathrm{Tg} \mathrm{yr}^{-1}$. Of the $141 \mathrm{Tg} \mathrm{yr}^{-1}$ (or $78.3 \mathrm{TgC} \mathrm{yr}^{-1}$ ) of POC mass emissions, only $7.7 \mathrm{Tg} \mathrm{yr}^{-1}(5 \%)$ partitions into the particle phase, without undergoing chemical reactions, to form POA. The remainder (POG) is chemically transformed in the atmosphere to form lower volatility products, some of which (49.8 $\mathrm{Tg} \mathrm{yr}^{-1}$ ) partitions into the condensed phase to form SI-SOA. SVOC oxidation forms $22.5 \mathrm{Tg} \mathrm{yr}^{-1}(45 \%)$ of SI-SOA which means that slightly less than half of the traditional POC emissions are "recovered" into the particle phase through the oxidation of SVOC vapors. IVOC oxidation forms $27.3 \mathrm{Tg} \mathrm{yr}^{-1}(55 \%)$ of the SI-SOA and hence contributes to more than half of the SI-SOA and to slightly less than a third (30\%) of the total OA formed, making it an important contributor to OA formation. 


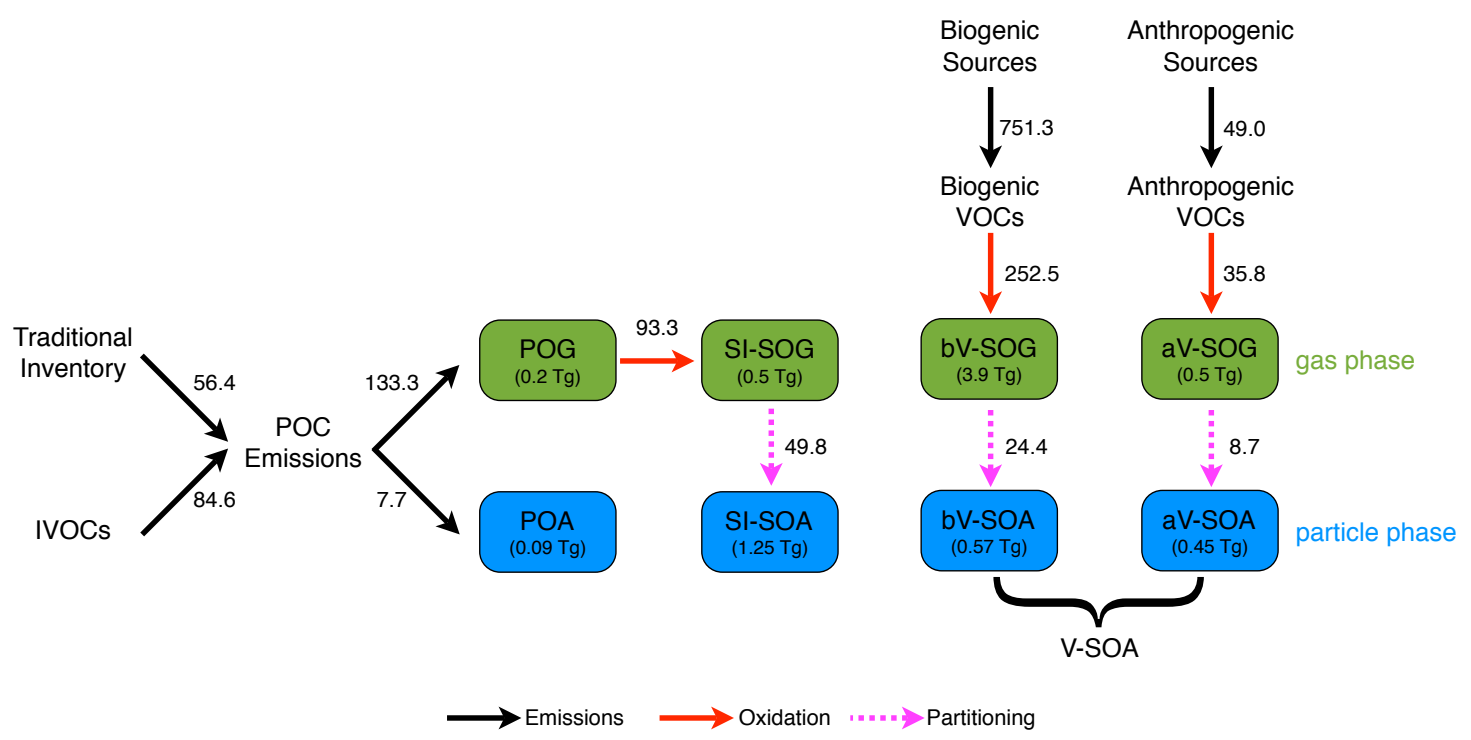

Fig. 6. Schematic showing annual production (arrows, $\mathrm{Tg}^{-1}{ }^{-1}$ ) and burdens (textboxes, $\mathrm{Tg}$ ) for the gas and particle phase classes of organic aerosol predicted by the BASE model.

We can divide the amount of SI-SOA formed by the amount of POG reacted to compute an effective aerosol mass yield of $53 \%$. The yield, when compared at a $C_{\mathrm{OA}}$ of $1 \mu \mathrm{g} \mathrm{m}^{-3}$, is much higher than the aerosol mass yields observed for biogenic VOCs like alpha-pinene $(4 \%)$ and isoprene $(1 \%)$ in smog chamber experiments (Farina et al., 2010). However, the yield is similar to those of aromatics like benzene (33\%) and naphthalene (66\%) (Ng et al., 2007; Chan et al., 2009). Hence, the mechanism used in this work to represent the gas-phase chemistry of POC would be similar to a traditional mechanism, which treated all POC like aromatics.

Table 4 lists the OA burdens from the different sensitivity runs in this work and those from previous studies. Across the set of sensitivity runs, the POA and SI-SOA burden, counted together, remains fairly constant $(1.34-1.45 \mathrm{Tg})$ except for in the NOIV and NOAG scenarios. This suggests that the OA burden is insensitive to the POC volatility distribution and the $\Delta H_{\text {vap. }}$. This is because changes in partitioning affected by changes in the volatility distribution and $\Delta H_{\text {vap }}$ are offset by the low volatility products formed via oxidation of the evaporated vapors. Further, the difference in total OA burden between the BASE and the NOIV scenario $(0.89 \mathrm{Tg})$ highlights the potential contribution that oxidation of IVOCs can have on the global burden ( $38 \%$ of the total). Of this $0.89 \mathrm{Tg}$, oxidation products of IVOCs contribute $0.73 \mathrm{Tg}$ directly and $0.16 \mathrm{Tg}$ indirectly by providing a larger absorbing phase which shifts the gas-particle partitioning towards the particle phase. In addition, the difference between the BASE and NOAG scenarios $(1.56 \mathrm{Tg}$ ) emphasizes the large contribution that POC oxidation or "aging" has on the OA burden.
While our estimate for the total OA produced $\left(90.6 \mathrm{Tg} \mathrm{yr}^{-1}\right)$ lies between that of previous studies $(63$ and $116 \mathrm{Tg} \mathrm{yr}^{-1}$ ) (Chung and Seinfeld, 2002; Kanakidou et al., 2005; Hoyle et al., 2007; Heald et al., 2008; Henze et al., 2008; Pye and Seinfeld, 2010), a detailed comparison of the burdens predicted by BASE reveal important differences from those predicted with models that treat POA as non-volatile and non-reactive (Koch, 2001; Chung and Seinfeld, 2002; Tsigaridis and Kanakidou, 2003; Liao and Seinfeld, 2005; Farina et al., 2010). The BASE model reduces the POA burden by an order of magnitude compared to those other models, which significantly changes the POA-SOA split. But, if the primary-in-origin OA, i.e. POA and SI-SOA, are considered together, the burden is similar to that predicted by other models. This indicates that the evaporated POC returns back to the condensed phase through the oxidation of SVOC and IVOC vapors to produce roughly the same burden one would predict in a model with non-volatile and non-reactive POA. Although we predict a similar burden, we estimate a very different spatial distribution of OA (Sect. 4.1.1) and a very different extent of oxygenation of OA (Sect. 4.2.2).

The BASE burdens are much closer to the predictions of Pye and Seinfeld (2010), which is the only other global model that accounts for semi-volatile and reactive POC. The BASE model predicts a POA/SOA split of $4 / 96 \%$ while Pye and Seinfeld (2010) predict it to be $2 / 98 \%$. In comparison, the TRAD model predicts a POA/SOA split of $47 / 53 \%$. Similarly, the BASE model predicts SI-SOA to account for $53 \%$ while Pye and Seinfeld (2010) predict SI-SOA to account for $54 \%$ of the total OA burden. 
Table 4. Burden and lifetime for organic aerosol and its classes.

\begin{tabular}{lrrrr}
\hline & POA & SI-SOA & V-SOA & OA \\
\hline Burden (Tg) & & & & \\
BASE/LOEM & 0.09 & 1.25 & 1.02 & 2.37 \\
LOVL & 0.45 & 1.00 & 1.04 & 2.48 \\
NOIV & 0.08 & 0.52 & 0.88 & 1.48 \\
HVAP & 0.15 & 1.21 & 2.07 & 3.43 \\
NOAG & 0.13 & 0.00 & 0.69 & 0.81 \\
Griffin et al. (1999) & - & - & 0.36 & - \\
Kanakidou et al. (2000) & -1.70 & - & $1.20-1.60$ & $2.90-3.20$ \\
Koch (2001) & 0.96 & - & - & - \\
Chung and Seinfeld (2002) & 1.20 & - & 0.19 & 1.39 \\
Derwent et al. (2003) & - & - & 1.40 & - \\
Tsigaridis and Kanakidou (2003) & - & - & $0.02-0.38$ & - \\
Lack et al. (2004) & - & - & 0.38 & - \\
Liao and Seinfeld (2005) & 1.27 & - & 0.33 & 1.60 \\
Farina et al. (2010) & 1.10 & - & 0.98 & 2.08 \\
Pye and Seinfeld (2010) & 0.03 & 0.90 & 0.71 & 1.65 \\
\hline Lifetime (days) & & & & \\
BASE & 0.6 & 9.2 & 11.2 & 9.6 \\
\hline
\end{tabular}

In this work, we used the model of Farina et al. (2010) to treat SOA formation from VOCs. However, since the simulation of POA and SOA is integrated under the VBS, changes in handling the POA can influence the V-SOA burden. Across the BASE, LOEM, LOVL and NOIV scenarios, the V-SOA burden does not change significantly. However, there is a two-fold increase in the V-SOA burden in the HVAP scenario due to the enhanced sensitivity of the gas-particle partitioning of biogenic V-SOCs to changes in temperature. Our model does not allow for aging of biogenic V-SOCs, which results in most $(90 \%)$ of the biogenic V-SOC mass to exist in the gas phase. In the free troposphere, where temperatures are lower, a lot of this gas-phase mass condenses into the particle phase yielding a higher burden in the HVAP scenario. In contrast, anthropogenic V-SOCs, which are allowed to age, account for only $13 \%$ of the total gas + particle mass burden with a much lower fraction (50\%) in the gas phase. Hence, we do not see a significant shift in the anthropogenic V-SOA burden due to the changes in temperature in the HVAP scenario.

\subsection{Comparison with field measurements}

To evaluate model performance, we compare predictions to a wider set of observations than considered by previous studies. The evaluation considers OA composition, volatility and isotopic composition in addition to surface OA mass concentrations. While total OA concentrations are important in understanding the abundance, the other metrics are useful in identifying the sources, chemistry and composition of ambient OA.

\subsubsection{Surface OA concentrations}

- United States: Fig. 7 shows scatter plots comparing model-predicted total OA surface mass concentrations from BASE, LOEM, LOVL, HVAP and NOAG with measured values from the Interagency Monitoring of Protected Visual Environments (IMPROVE) network (IMPROVE, August, 1995). Table 5 presents the statistical performance metrics for all the model runs including the TRAD scenario. The IMPROVE network measures PM concentrations across $\sim 200$, mostly remote/rural, locations within the United States. Each point on the scatter plot represents a monthly averaged value at a particular grid cell. The IMPROVE network reports $\mathrm{OA}$ mass concentrations in $\mu \mathrm{g} \mathrm{C} \mathrm{m}^{-3}$. To compare with model predictions they are converted to $\mu \mathrm{g} \mathrm{m}^{-3}$ using a conservative organic-mass-to-organiccarbon ratio of 1.8 , based on the work of Turpin and Lim (2001) and Aiken et al. (2008). In Fig. 7, red points represent the summer months of June, July and August and blue points represent the winter months of December, January and February.

We initially compare observations to results from the BASE scenario (Fig. 7a) and then highlight differences amongst the different sensitivity cases. In summer, the BASE predictions for OA surface mass concentration lie within a factor of 2 of observations with little bias. The winter-time predictions of the BASE model, however, are centered around the 1:2 dashed line with most $(83 \%)$ predictions lying within a factor of 5 . 


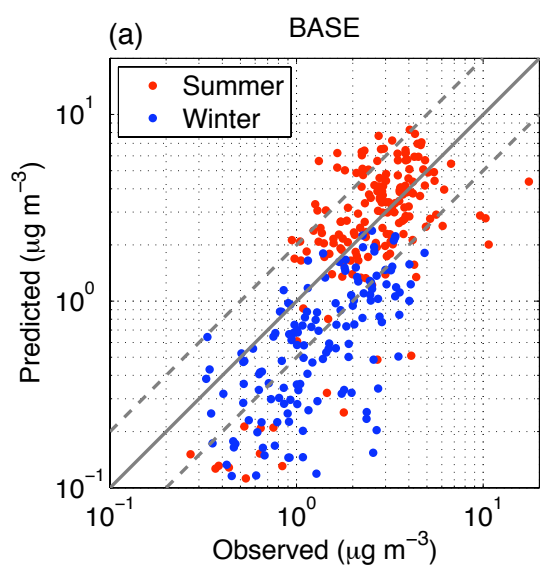

(d)

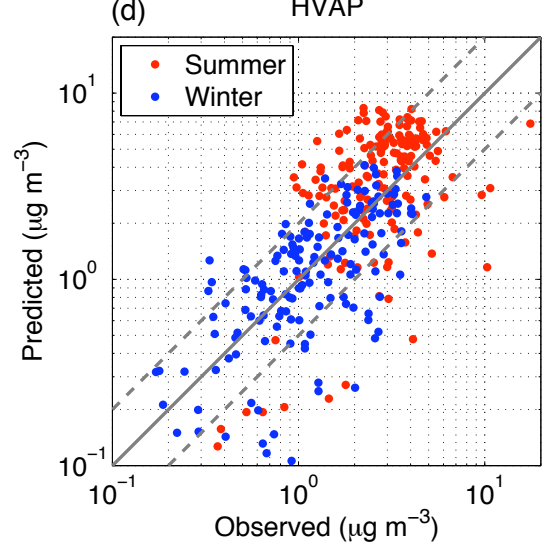

(b)

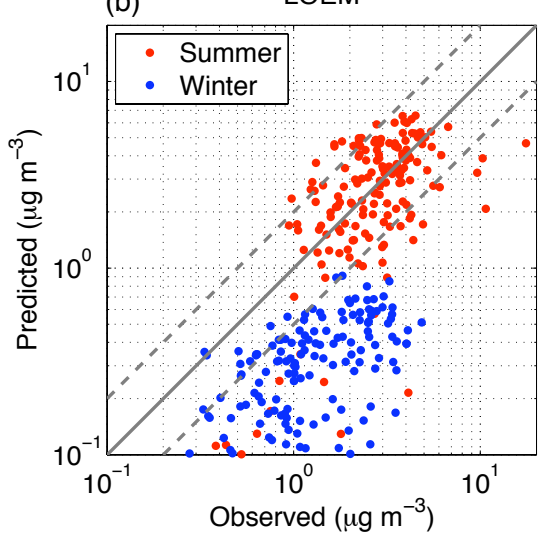

(c)

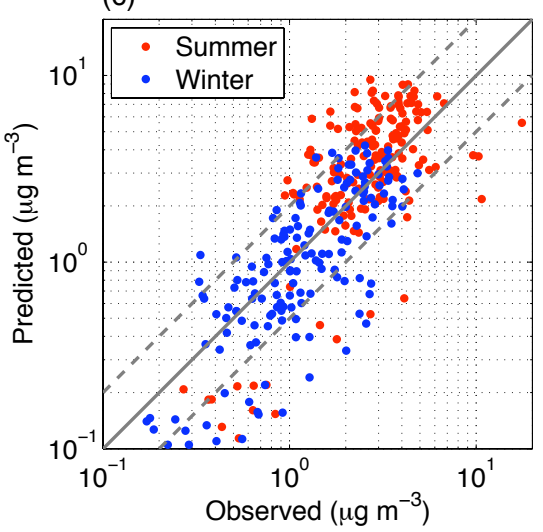

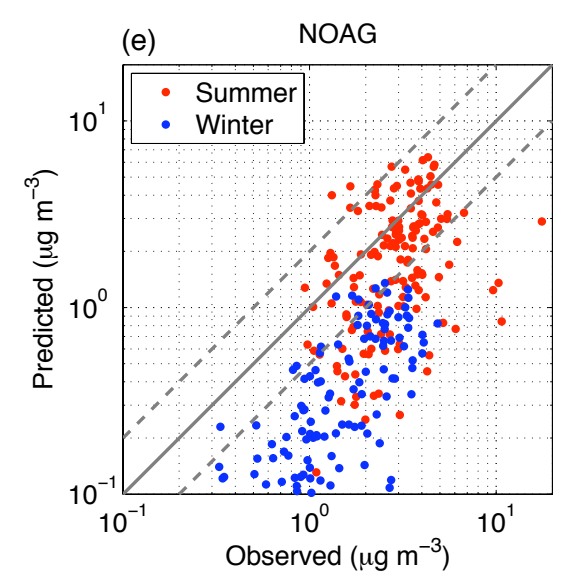

Fig. 7. Scatter plots comparing model predictions from BASE, LOEM, LOVL, HVAP and NOAG with observations at IMPROVE sites from the 2001 to 2002. Red represents the summer months of June, July and August (JJA) and blue represents the winter months of December, January and February (DJF). The solid grey line is the 1:1 line and the dashed lines are the 1:2 and 2:1 lines.

Statistical metrics of fractional bias and fractional error were calculated to quantitatively evaluate model performance.

Fractional Bias $=\frac{1}{N} \sum_{i=1}^{N} \frac{M-O}{\frac{M+O}{2}}$

Fractional Error $=\frac{1}{N} \sum_{i=1}^{N} \frac{|M-O|}{\frac{M+O}{2}}$

where $M$ are predicted values, $O$ are observed values and $N$ is the sample size.

For the BASE scenario, both the fractional bias and fractional error are smaller in summer than in winter. The TRAD model, in comparison, has similar performance metrics in summer but better metrics in winter than the BASE model. So on an absolute OA mass concentration basis, the TRAD model performs better than the BASE model due to differences in wintertime results. In the BASE model, reduced photochemistry in winter results in reduced aerosol formation through gas-phase oxidation of POC emissions. The TRAD model, on the other hand, predicts higher OA concentrations because none of the POC emissions evaporate. We are not surprised by the TRAD model performance because Park et al. (2006), using the same emissions inventory and IMPROVE observations, arrived at a similarly good model-measurement comparison. Park et al. (2006) achieved the better model performance by increasing the fossil and biofuel OC emissions over North America by a factor of $\sim 2$.

Figure $7 \mathrm{~b}$ indicates that the lower emissions (in the LOEM case) lead to a greater under-prediction during the winter months without significantly changing the summer comparison. This result is consistent with the finding of Heald et al. (2006a) that North American winter-time predictions using the Bond et al. (2004) inventory are low when compared to observations. The lower volatility distribution (in the LOVL case) improves winter performance without significantly changing the summer performance. This occurs because the 
Table 5. Statistical metrics to evaluate comparison between model results from BASE, TRAD, LOEM, LOVL, HVAP and the IMPROVE network for summer, winter and the entire year.

\begin{tabular}{|c|c|c|c|c|c|}
\hline & & $\begin{array}{r}\text { Fractional Bias } \\
(\%)\end{array}$ & $\begin{array}{r}\text { Fractional Error } \\
(\%)\end{array}$ & $\begin{array}{r}\text { Observed Mean } \\
\left(\mu \mathrm{g} \mathrm{m}^{-3}\right)\end{array}$ & $\begin{array}{r}\text { Predicted Mean } \\
\left(\mu \mathrm{g} \mathrm{m}^{-3}\right)\end{array}$ \\
\hline \multirow{3}{*}{ BASE } & Summer & -6 & 48 & 3.0 & 3.0 \\
\hline & Winter & -84 & 86 & 1.5 & 0.6 \\
\hline & Annual & -36 & 58 & 2.1 & 1.7 \\
\hline \multirow{3}{*}{ TRAD } & Summer & 6 & 54 & 3.0 & 3.7 \\
\hline & Winter & -10 & 48 & 1.5 & 1.5 \\
\hline & Annual & 2 & 52 & 2.1 & 2.6 \\
\hline \multirow{3}{*}{ LOEM } & Summer & -17 & 47 & 3.0 & 2.7 \\
\hline & Winter & -124 & 124 & 1.5 & 0.3 \\
\hline & Annual & -58 & 73 & 2.1 & 1.4 \\
\hline \multirow{3}{*}{ LOVL } & Summer & 11 & 50 & 3.0 & 3.7 \\
\hline & Winter & -26 & 50 & 1.5 & 1.3 \\
\hline & Annual & 3 & 49 & 2.1 & 2.4 \\
\hline \multirow{3}{*}{ HVAP } & Summer & 9 & 57 & 3.0 & 3.6 \\
\hline & Winter & -22 & 52 & 1.5 & 1.2 \\
\hline & Annual & 1 & 54 & 2.1 & 2.4 \\
\hline \multirow{3}{*}{ NOAG } & Summer & -59 & 75 & 3.0 & 2.0 \\
\hline & Winter & -135 & 135 & 1.5 & 0.3 \\
\hline & Annual & -98 & 104 & 2.1 & 1.0 \\
\hline
\end{tabular}

OA formed from primary organic sources (POA and SISOA) accounts for a larger fraction of the winter OA $(65 \%)$ than the summer OA (30\%). Hence, any change in the magnitude or volatility distribution of POC emissions has a bigger influence over the OA mass concentrations in winter than in summer. The HVAP scenario, using a wider range of enthalpy of vaporization values, better reproduces the winter data with a slight over-prediction during the summer. Overall, both the LOVL and HVAP scenarios better predict the absolute OA concentrations than the BASE and LOEM scenarios due to an improved winter-time comparison. Both LOVL and HVAP predict, on an annual basis, a negligible fractional bias and a fractional error of $\sim 50 \%$. Model predictions from the NOAG scenario suggest that the model-measurement comparison worsens as the OA mass concentration decreases. That model does well in polluted locations (high OA mass concentrations) presumably because the OA is very close to the source and is still fresh. This implies that as the OA moves away from source regions, there is an enhancement in the OA mass that the NOAG model is not able to reproduce. It is clear, when compared to the BASE scenario, that aging the POC emissions is an essential process that needs to be modeled in order to enable a better model-measurement comparison.
Presumably, the wintertime comparison could also be improved by aging biogenic SOA. However, given that biogenic VOC emissions are higher and photochemical processing is stronger in the summer, aging biogenic SOA at the same rate as anthropogenic SOA would influence the summertime IMPROVE comparison much more than the wintertime IMPROVE comparison.

- Rest of the World: Fig. 8 shows scatter plots comparing model-predicted OA surface mass concentrations from BASE, LOVL, NOIV, HVAP and NOAG with observations from across the globe (Liousse et al., 1996; Chung and Seinfeld, 2002; Zhang et al., 2007). The performance in the summer and winter months across the four comparisons is similar to that shown in Fig. 7. The scatter, however, is much greater than the IMPROVE comparisons and the predictions sometimes lie an order of magnitude below observations. For example, for the BASE case, the annual fractional bias is $-83 \%$ and the fractional error is $105 \%$, both much larger than the annual IMPROVE metrics. The large scatter might be due to inconsistent and non-standardized measurement methods used by the different global networks such as differences in artifact correction, carbon analysis method or sampling duration. The IMPROVE network, in contrast, is an integrated effort employing standardized protocols and instruments for measurement, making it a much more consistent dataset to compare against. 

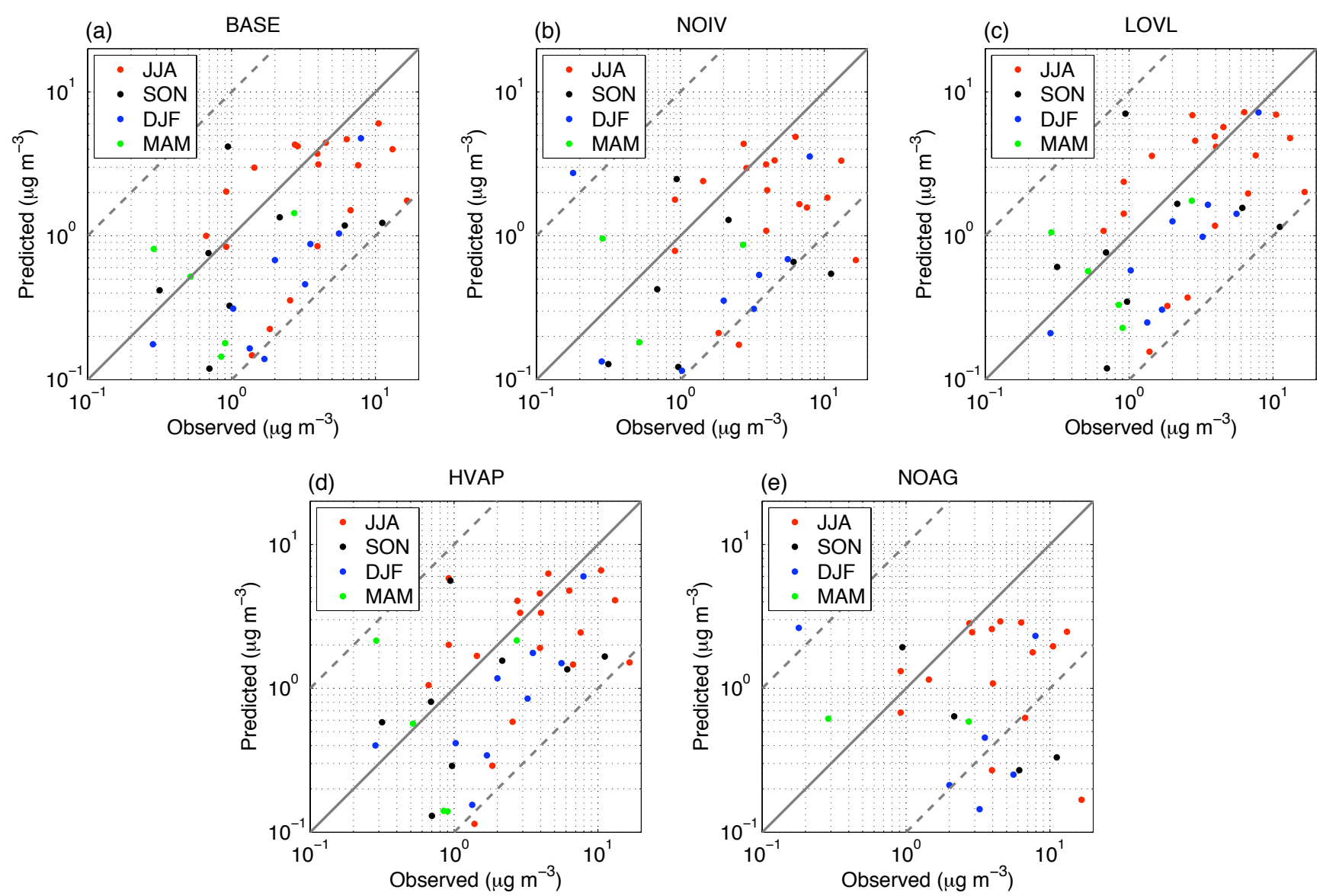

Fig. 8. Scatter plot comparing model predictions from BASE, LOVL, NOIV, HVAP and NOAG with observed values at rural, remote and marine sites across the globe (Liousse et al., 1996; Chung and Seinfeld, 2002; Zhang et al., 2007). Red represents the months of June, July and August (JJA), black represents the months of September, October and November (SON), blue represents the months of December, January and February (DJF) and green represents the months of March, April and May (MAM) The solid grey line is the 1:1 line and the dashed lines are the 1:10 and 10:1 lines.

\subsubsection{Oxygenated organic aerosol}

Recent work, using Aerosol Mass Spectroscopy and factor analysis, has identified two chemically distinct classes of OA: hydrocarbon-like OA (HOA) and oxygenated OA (OOA) (Zhang et al., 2005). HOA is oxygen depleted OA and is associated with fresh POA emissions; and OOA is oxygen rich OA and is associated with aged OA/SOA and biomass burning (Zhang et al., 2005, 2007; Robinson et al., 2007; Donahue et al., 2009). Zhang et al. (2007) estimated the fraction of HOA and OOA in OA at numerous locations around the world. We compare those estimates with model predictions assuming $\mathrm{HOA}$ to be equivalent to POA and OOA to be a sum of SI-SOA and V-SOA. Based on our discussion in Sect. 2.1.4, for the TRAD model, we consider all non-volatile POA to be "unaged" and therefore as HOA and $\mathrm{V}-\mathrm{SOA}$ to be OOA.
Figure 6a compares the observed OOA-to-OA ratio at urban-downwind and rural/remote locations to predictions of the SOA-to-OA ratio from the TRAD and BASE models. The comparison deliberately omits urban locations due to the GCM's low spatial resolution. The observations indicate that OOA accounts for a large fraction of ambient OA. The BASE case reproduces more accurately the fraction of OOA with model predictions lying between -21 and $+27 \%$ of observations. In comparison, the TRAD model, on an average, under-predicts the OOA fraction by a factor of two. To determine the sensitivity of the model predictions to different input parameters, we calculate a concentration-weighted average SOA-to-OA ratio for the urban-downwind and ru$\mathrm{ral} /$ remote location categories for the various sensitivity runs. The sensitivity runs predict a range from 0.79 to 0.93 for the urban-downwind locations and 0.71 to 0.90 for rural/remote locations respectively. The observed average, in comparison, was 0.83 and 0.95 . In contrast, the TRAD model-predicted 
average was 0.56 and 0.45 respectively. This suggests that a high SOA-to-OA ratio that is consistent with observations is an outcome of the revised framework (semi-volatile and reactive POA) and is not sensitive across the range of possible input parameters. Therefore, the revised framework better predicts the high fractional contribution of SOA as reported by field studies.

\subsubsection{OA volatility}

Figure 9 compares model-predicted OA volatility to measurements from three different field campaigns: (a) FAME campaign in May-June 2008 (FAME-2008) at Finokalia, a remote site in the northeast of Crete, Greece, (b) Mexico City campaign in March-April 2006 (MILAGRO-2006) and (c) Riverside campaign in July-August 2005 (SOAR-2005). The OA volatility was measured using thermodenuders and is represented as a thermogram, which is a plot of the OA mass fraction remaining as a function of temperature. The measured thermograms have been corrected for non-equilibrium effects in the thermodenuder using the work of Lee et al. (2010) for FAME-2008 and the work of Cappa and Jimenez (2010) for MILAGRO-2006. For SOAR-2005, the thermogram has not been corrected for non-equlibrium conditions in the thermodenuder. A thermogram for the model predictions is computed using a simple equilibrium model that changes the OA gas-particle partitioning with temperature based on the Clausius-Clapeyron equation.

At all three locations, the BASE case predicts the OA volatility better than the TRAD case. The initial decrease in the mass fraction remaining for the TRAD model is due to the evaporation of semi-volatile V-SOC. At higher temperatures, the flat response of the thermogram reflects the remaining POA, which is treated as non-volatile by the TRAD model and does not evaporate at any temperature. Amongst the various sensitivity runs, the NOIV scenario predicts a somewhat more volatile OA while the LOVL predicts a somewhat lower volatility $\mathrm{OA}$; however, these differences are likely to be within the measurement uncertainty. The HVAP case, in contrast, predicts a much higher volatility OA, overpredicting the evaporation of ambient OA with temperature and highlighting the sensitivity of the gas-particle partition-

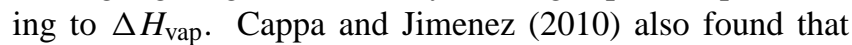
Epstein et al. (2010) formulation of $\Delta H_{\text {vap }}$ produces a much too strong $C^{*}$ sensitivity to temperature.

For the MILAGRO data-set, a possible explanation for a higher observed volatility could be the proximity of the measurement site (T0 supersite) to the urban source region. This means a shorter time for aging and thus a potentially more volatile OA. The model results, on the other hand, are representative of a well-mixed and aged aerosol in a $4^{\circ}$ latitude x $5^{\circ}$ longitude grid cell. In contrast, FAME-2008 is a better data-set to evaluate the model predictions against because it is isolated from large sources and therefore indicative of OA
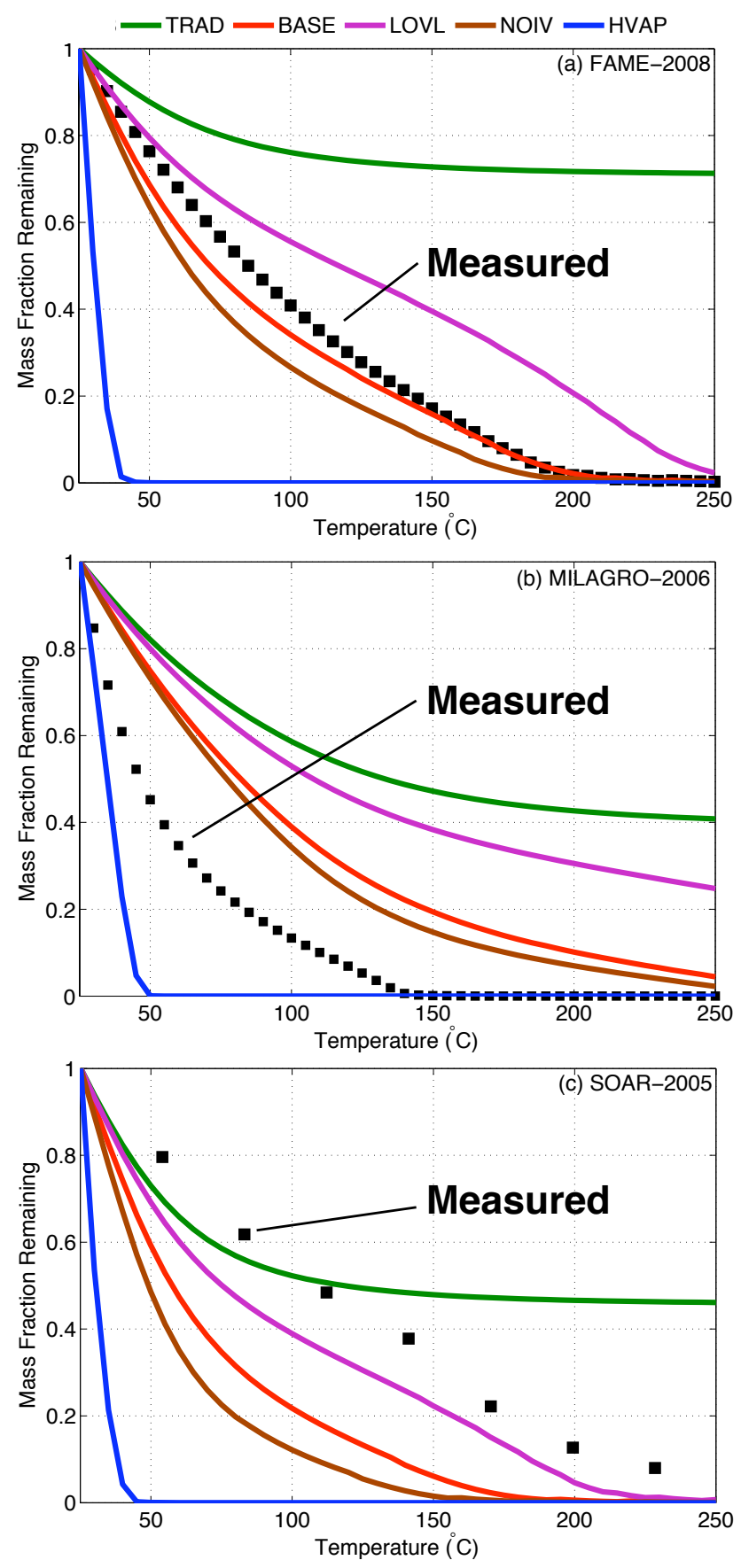

Fig. 9. Thermograms comparing equilibrium-corrected data from the (a) the FAME-2008 campaign and (b) MILAGRO-2006 campaign with model results. (c) Thermogram comparing raw measured data from SOAR-2005 with model results. Data are from Lee et al. (2010), Cappa and Jimenez (2010) and Huffman et al. (2009b).

transported and aged over longer distances. For the SOAR dataset, the BASE scenario predicts a slightly more volatile OA perhaps because the field data is not in equilibrium during measurement. 

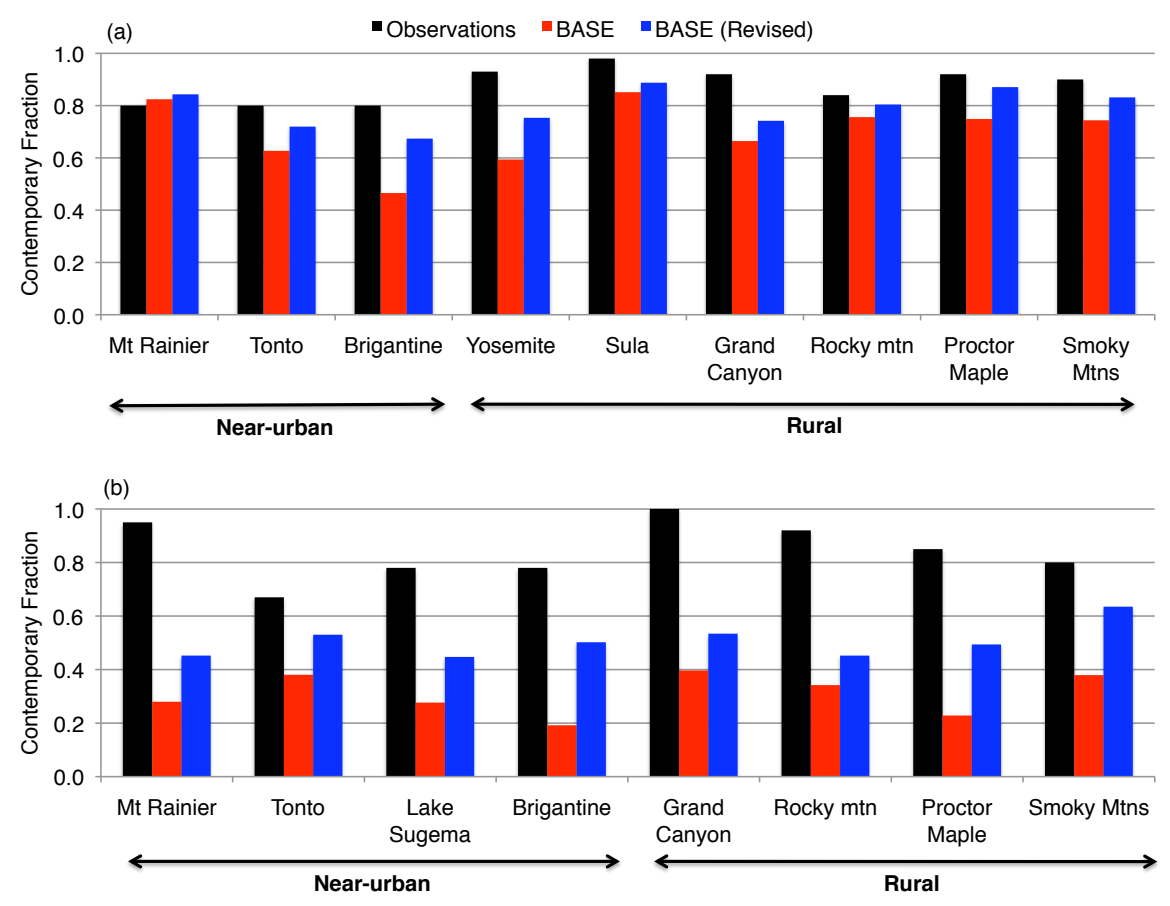

Fig. 10. Contemporary fraction of OA at IMPROVE sites during the (a) summer and (b) winter months compared with model results from BASE and BASE (Revised). Data are from Schichtel et al. (2008).

\subsubsection{OA isotopic composition}

The radioactive isotope of carbon $\left({ }^{14} \mathrm{C}\right)$ is used to distinguish fossil (coal, gasoline, diesel) and contemporary (wood, agricultural waste, pollen, vegetation) contributions to ambient OA (Szidat, 2009). Schichtel et al. (2008) present the isotopic composition for 12 rural sites collocated with the IMPROVE network. Figure 10 shows a comparison between Schichtel et al. (2008) measured contemporary fractions during the (a) summer and (b) winter months and model results from the BASE scenario (all sensitivity runs predict similar results). To calculate the fossil and contemporary fractions, we include both OC and EC. Fossil carbon includes EC, POA and anthropogenic SOA from fossil fuel sources. Contemporary carbon includes EC, POA and anthropogenic SOA from biofuels and open burning, and biogenic SOA. The emission inventory for VOC precursors of aV-SOA do not allow for separate tracking of fossil and contemporary sources. Hence, we divide aV-SOA into its fossil and contemporary fractions in the same proportion as the total annual fossil and contemporary emissions of anthropogenic VOCs in the US.

For summer, the observed contemporary fractions vary from 0.8 to 1.0 , which the BASE model slightly underpredicts (0.62 to 0.85$)$. In winter, the observed contemporary fractions range from 0.67 to 1.0 which are significantly under-predicted by the BASE model ( 0.35 to 0.55$)$. There are two possible reasons for the shortcoming of the model in predicting the contemporary fraction in winter. First, for the observations, the EC on average, accounts for $15 \%$ of the total carbon (TC) in summer and $22 \%$ of the TC in winter. In comparison, the BASE model predicts that $\mathrm{EC}$ on average, accounts for $22 \%$ of the TC in summer and $60 \%$ of the TC in winter. Hence, the BASE model predicts the correct EC:TC ratio in the summer but over-predicts EC concentrations in the winter, which are mostly fossil in origin (80\% of US EC emissions), at all locations except Mt Rainier (refer to Fig. S1 in Supplement). Second, the BASE scenario under-predicts OC concentrations in winter, which are mostly contemporary in origin (78\% of US OC emissions), at all locations except Grand Canyon. This leads to a larger fossil fraction and a smaller contemporary fraction in winter. Therefore, lower predicted EC concentrations and higher predicted OC concentrations will likely improve wintertime comparisons. To that effect, we take EC concentrations from the LOEM (LOw EMissions) scenario and pair them with OC concentrations from the LOVL (LO VoLatility) scenario to predict the contemporary fraction. This combination, labelled "BASE revised" modestly improves the comparison during the winter months.

It is also possible that the model-predicted contemporary fraction in winter is low because the biogenic SOA, which is all contemporary, is not allowed to age. However, as mentioned in Sect. 4.2.1, this would badly over-predict the summertime OA mass concentration as was seen by Lane et al. (2008) and Murphy and Pandis (2009). Hence, it is not clear whether the aging of biogenic SOA is important in predicting the correct contemporary fraction in winter. 


\section{Discussion and conclusions}

In this work, we develop a global OA model that treats POA as semi-volatile and reactive and incorporates the emissions and oxidation of IVOCs as an additional source of OA. The OA model employs the volatility basis set (VBS) framework to simulate the emissions, chemical reactions and phase partitioning of all OA. Model sensitivity was assessed by varying the POC emissions, POC volatility distribution, IVOC emissions, partitioning process and photochemical aging.

The BASE version of the revised model predicts an annual OA production rate of $90.6 \mathrm{Tg} \mathrm{yr}^{-1}$ and a global burden of $2.37 \mathrm{Tg}$. In contrast to previous models that treat POA as non-volatile and non-reactive, the revised model predicts that most of OA is SOA, i.e. formed from the oxidation of vapor/gas phase organics. This happens because most of the POA evaporates and reacts with atmospheric oxidants to form low volatility products that condense into the particle phase as SI-SOA. This brings the POA/SOA split predicted by the revised model in better agreement with ambient measurements. This work also emphasizes the importance of oxidation of IVOCs as an additional source of OA. The revised model predicts that IVOCs contribute to more than a third of the total OA formed in the atmosphere. This implies that global and regional models that do not account for IVOCs could be under-estimating OA formation by $50 \%$. The amount of OA arising from IVOC oxidation depends on the magnitude of IVOC emissions and the mechanisms that model its oxidation in the atmosphere, both of which remain fairly uncertain. Pye and Seinfeld (2010) use a different method to model IVOC emissions and reactivity, and hence predict a very different (5\% compared to our $30 \%$ ) contribution of IVOCs to the global OA budget. If we wish to determine their true influence, more effort needs to be made to constrain their emissions and reactivity in the atmosphere.

We evaluated model performance by comparing predictions not only against ambient OA mass concentrations but also against observations that provide insight into the sources, chemistry and properties of OA. These additional observations include degree of oxygenation, volatility and isotopic composition. The revised versions of the model perform much better on all those additional observations than the traditional version of the model. This illustrates that by treating POA as semi-volatile and reactive and accounting for emissions and oxidation of IVOCs, we have improved the model's capability in predicting the sources, chemistry and properties of OA. For example, we are able to predict the degree-of-oxygenation of OA. This has important implications for climate models that determine the effects of aerosols on radiative forcing since oxygenated OA have a higher propensity to uptake water and affect cloud formation. We are also able to predict the volatility of OA which is important in determining its lifetime and fate in the atmosphere.
Amongst the sensitivity runs, the scenario where IVOC emissions are set to zero does reasonably well in predicting the observed degree-of-oxygenation and volatility but significantly under-predicts wintertime OA surface mass concentrations over the United States. The BASE version performs similar to the no-IVOC version but has a slightly better wintertime performance. The simulation, where we use the parameterization by Epstein et al. (2010) to represent the enthalpy of vaporization, performs well in predicting the OA mass concentrations over the United States and the degree-of-oxygenation. But, it predicts an ambient OA that has a very high volatility compared to measurements at the FAME, MILAGRO and SOAR field campaigns. The low volatility version of the model, however, performs reasonably well across all three metrics. Given the simulations performed in this work, we could argue that to get model predictions to agree with observations across mass concentrations, degree-of-oxygenation and volatility, the ideal model would need a (1) high IVOC contribution to the OA burden, (2) volatility lower than that of diesel exhaust for POC emissions and (3) a lower sensitivity of the OA to changes in temperature than those proposed by Epstein et al. (2010).

A comparison of OA surface mass concentrations between the revised model and the IMPROVE network revealed good agreement in the summer months and an under-prediction in the winter months. The sensitivity runs suggest that the comparison during the winter months can be improved, without affecting the summer comparison, by increasing emissions or decreasing the volatility of the POC emissions. The under-prediction of OA mass concentrations and the contemporary fraction in winter lead us to hypothesize that the emission inventory is probably under-representing a contemporary source in winter. To support that argument, Bond et al. (2004) show that about $60 \%$ of contained POC emissions in the US are from residential biofuel use and that more than $50 \%$ of the uncertainty in those emissions arises from residential wood burning. Hence, it is likely that residential biofuel emissions are under-represented in the emission inventory in winter.

Models that simulate the abundance and properties of OA need to account for the semi-volatile and reactive nature of POA. However, there are currently significant uncertainties in building models that represent that behavior. Future work needs to focus on quantifying the total (vapor + particle) emissions, volatility and atmospheric processing of POC. Further, models that are used to simulate OA need to be evaluated by comparing model predictions with observations of intensive properties that provide clues about their physical and chemical processes: degree of oxygenation, volatility and isotopic composition.

\section{Supplementary material related to this article is available online at: http://www.atmos-chem-phys.net/11/7727/2011/ acp-11-7727-2011-supplement.pdf.}


Acknowledgements. This work was supported by the EPA STAR program through the National Center for Environmental Research (NCER) under grants RD-83337401-0 and R833748.

Edited by: M. Kanakidou

\section{References}

Adams, P., Seinfeld, J., and Koch, D.: Global concentrations of tropospheric sulfate, nitrate, and ammonium aerosol simulated in a general circulation model, J. Geophys. Res..-Atmos., 104, 13791-13823, 1999.

Aiken, A., DeCarlo, P., Kroll, J., Worsnop, D., Huffman, J., Docherty, K., Ulbrich, I., Mohr, C., Kimmel, J., Sueper, D., et al.: $\mathrm{O} / \mathrm{C}$ and $\mathrm{OM} / \mathrm{OC}$ ratios of primary, secondary, and ambient organic aerosols with high-resolution time-of-flight aerosol mass spectrometry, Environ. Sci. Technol., 42, 4478-4485, 2008.

An, W., Pathak, R., Lee, B., and Pandis, S.: Aerosol volatility measurement using an improved thermodenuder: Application to secondary organic aerosol, J. Aerosol Sci., 38, 305-314, 2007.

Asa-Awuku, A., Miracolo, M., Kroll, J., Robinson, A., and Donahue, N.: Mixing and phase partitioning of primary and secondary organic aerosols, Geophys. Res. Lett.., 36, L15827, doi:10.1029/2009GL039301, 2009.

Bernstein, J., Alexis, N., Barnes, C., Bernstein, I., Bernstein, J., Nel, A., Peden, D., Diaz-Sanchez, D., Tarlo, S., and Williams, P.: Health effects of air pollution, The J. Allerg. Clin. Immun., 114, 1116-1123, 2004.

Bond, T., Streets, D., Yarber, K., Nelson, S., Woo, J., and Klimont, Z.: A technology-based global inventory of black and organic carbon emissions from combustion, J. Geophys. Res., 109, D14203, doi:10.1029/2003JD003697, 2004.

Cappa, C. D. and Jimenez, J. L.: Quantitative estimates of the volatility of ambient organic aerosol, Atmos. Chem. Phys., 10, 5409-5424, doi:10.5194/acp-10-5409-2010, 2010.

Chan, A. W. H., Kautzman, K. E., Chhabra, P. S., Surratt, J. D., Chan, M. N., Crounse, J. D., Kürten, A., Wennberg, P. O., Flagan, R. C., and Seinfeld, J. H.: Secondary organic aerosol formation from photooxidation of naphthalene and alkylnaphthalenes: implications for oxidation of intermediate volatility organic compounds (IVOCs), Atmos. Chem. Phys., 9, 3049-3060, doi:10.5194/acp-9-3049-2009, 2009.

Chung, S. and Seinfeld, J.: Global distribution and climate forcing of carbonaceous aerosols, J. Geophys. Res., 107(D19), 4407, doi:10.1029/2001JD001397, 2002.

Cooke, W., Liousse, C., Cachier, H., and Feichter, J.: Construction of a $1^{\circ} \times 1^{\circ}$ fossil fuel emission data set for carbonaceous aerosol and implementation and radiative impact in the ECHAM4 model, J. Geophys. Res., 104, 22-137, 1999.

De Gouw, J., Middlebrook, A., Warneke, C., Goldan, P., Kuster, W., Roberts, J., Fehsenfeld, F., Worsnop, D., Canagaratna, M., Pszenny, A., Keene, W. C., Marchewka, M., Bertman, S. B., and Bates T. S.: Budget of organic carbon in a polluted atmosphere: Results from the New England Air Quality Study in 2002, J. Geophys. Res., 110, 1-22, 2005.

Del Genio, A. and Yao, M.: Efficient cumulus parameterization for long-term climate studies: The GISS scheme, The Representation of Cumulus Convection in Numerical Models, Meteor. Monogr, 46, 181-184, 1993.
Del Genio, A., Yao, M., Kovari, W., and Lo, K.: A prognostic cloud water parameterization for global climate models, J. Climate, 9, 270-304, 1996.

Donahue, N., Robinson, A., Stanier, C., and Pandis, S.: Coupled partitioning, dilution, and chemical aging of semivolatile organics, Environ. Sci. Technol., 40, 2635-2643, 2006.

Donahue, N., Robinson, A., and Pandis, S.: Atmospheric organic particulate matter: From smoke to secondary organic aerosol, Atmos. Environ., 43, 94-106, 2009.

Derwent, R., Collins, W., Jenkin, M., Johnson, C. and Stevenson, D.: The global distribution of secondary particulate matter in a 3-D Lagrangian chemistry transport model, J. Atmos. Chem., 44, 57-95, 2003.

Dzepina, K., Volkamer, R. M., Madronich, S., Tulet, P., Ulbrich, I. M., Zhang, Q., Cappa, C. D., Ziemann, P. J., and Jimenez, J. L.: Evaluation of recently-proposed secondary organic aerosol models for a case study in Mexico City, Atmos. Chem. Phys., 9, 5681-5709, doi:10.5194/acp-9-5681-2009, 2009.

El-Zanan, H., Lowenthal, D., Zielinska, B., Chow, J., and Kumar, N.: Determination of the organic aerosol mass to organic carbon ratio in IMPROVE samples, Chemosphere, 60, 485-496, 2005.

Epstein, S., Riipinen, I., and Donahue, N.: A Semiempirical Correlation between Enthalpy of Vaporization and Saturation Concentration for Organic Aerosol, Environ. Sci. Technol., 44(2), 743748,2010

Farina, S. C., Adams, P. J., and Pandis, S. N.: Modeling global secondary organic aerosol formation and processing with the volatility basis set: Implications for anthropogenic secondary organic aerosol, J. Geophys. Res., 115, D09202, doi:10.1029/2009JD013046, 2010.

Grieshop, A., Miracolo, M., Donahue, N., and Robinson, A.: Constraining the volatility distribution and gas-particle partitioning of combustion aerosols using isothermal dilution and thermodenuder measurements, Environ. Sci. Technol., 43, 4750-4756, 2009a.

Grieshop, A. P., Logue, J. M., Donahue, N. M., and Robinson, A. L.: Laboratory investigation of photochemical oxidation of organic aerosol from wood fires 1: measurement and simulation of organic aerosol evolution, Atmos. Chem. Phys., 9, 1263-1277, doi:10.5194/acp-9-1263-2009, 2009b.

Griffin, R. J., Cocker III, D. R., Seinfeld, J. H., and Dabdub, D.: Estimate of global atmospheric organic aerosol from oxidation of biogenic hydrocarbons, Geophys. Res. Lett., 26(17), 27212724, 1999.

Hansen, J., Russell, G., Rind, D., Stone, P., Lacis, A., Lebedeff, S., Ruedy, R., and Travis, L.: Efficient three-dimensional global models for climate studies: Models I and II, Mon. Weather Review., 111, 609-662, 1983.

Heald, C., Jacob, D., Park, R., Russell, L., Huebert, B., Seinfeld, J., Liao, H., and Weber, R.: A large organic aerosol source in the free troposphere missing from current models, Geophys. Res. Lett., 32, L18809, doi:10.1029/2005GL023831, 2005.

Heald, C., Jacob, D., Turquety, S., Hudman, R., Weber, R., Sullivan, A., Peltier, R., Atlas, E., De Gouw, J., Warneke, C., Holloway, J. S., Neuman, J. A., Flocke, F. M., and Seinfeld, J. H.: Concentrations and sources of organic carbon aerosols in the free troposphere over North America, J. Geophys. Res., 111, D23S47, doi:10.1029/2006JD007705, 2006a.

Heald, C. L., Jacob, D. J., Park, R. J., Alexander, B., Fairlie, T. 
D., Yantosca, R. M., and Chu, D. A.: Transpacific transport of Asian anthropogenic aerosols and its impact on surface air quality in the United States, J. Geophys. Res., 111, D14310, doi:10.1029/2005JD006847, 2006b.

Heald, C., Henze, D., Horowitz, L., Feddema, J., Lamarque, J., Guenther, A., Hess, P., Vitt, F., Seinfeld, J., Goldstein, A., and Fung, I.: Predicted change in global secondary organic aerosol concentrations in response to future climate, emissions, and land use change, J. Geophys. Res., 113, D05211, doi:10.1029/2007JD009092, 2008.

Henze, D. K., Seinfeld, J. H., Ng, N. L., Kroll, J. H., Fu, T.-M., Jacob, D. J., and Heald, C. L.: Global modeling of secondary organic aerosol formation from aromatic hydrocarbons: highvs. low-yield pathways, Atmos. Chem. Phys., 8, 2405-2420, doi:10.5194/acp-8-2405-2008, 2008.

Hoyle, C. R., Berntsen, T., Myhre, G., and Isaksen, I. S. A.: Secondary organic aerosol in the global aerosol - chemical transport model Oslo CTM2, Atmos. Chem. Phys., 7, 5675-5694, doi:10.5194/acp-7-5675-2007, 2007.

Huffman, J. A., Docherty, K. S., Aiken, A. C., Cubison, M. J., Ulbrich, I. M., DeCarlo, P. F., Sueper, D., Jayne, J. T., Worsnop, D. R., Ziemann, P. J., and Jimenez, J. L.: Chemically-resolved aerosol volatility measurements from two megacity field studies, Atmos. Chem. Phys., 9, 7161-7182, doi:10.5194/acp-9-71612009, 2009a.

Huffman, J., Docherty, K., Mohr, C., Cubison, M., Ulbrich, I., Ziemann, P., Onasch, T., and Jimenez, J.: Chemicallyresolved volatility measurements of organic aerosol fom different sources., Environ. Sci. Technol., 43, 5351-5357, 2009 b.

IMPROVE: IMPROVE Data Guide, August, 1995.

IPCC, W.: Climate change 2007: the physical science basis, Summary for Policy Makers, Contribution of Working Group I to the Fourth Assessment Report of the Intergovernmental Panel on Climate Change, 2007.

DeCarlo, P. F., Allan, J. D., Coe, H., Ng, N. L., Aiken, A. C., Docherty, K. S., Ulbrich, I. M., Grieshop, A. P., Robinson, A. L., Duplissy, J., Smith, J. D., Wilson, K. R., Lanz, V. A., Hueglin, C., Sun, Y. L., Tian, J., Laaksonen, A., Raatikainen, T., Rautiainen, J., Vaattovaara, P., Ehn, M., Kulmala, M., Tomlinson, J. M., Collins, D. R., Cubison, M. J., Dunlea, E. J., Huffman, J. A., Onasch, T. B., Alfarra, M. R., Williams, P. I., Bower, K., Kondo, Y., Schneider, J., Drewnick, F., Borrmann, S., Weimer, S., Demerjian, K., Salcedo, D., Cottrell, L., Griffin, R., Takami, A., Miyoshi, T., Hatakeyama, S., Shimono, A., Sun, J. Y., Zhang, Y. M., Dzepina, K., Kimmel, J. R., Sueper, D., Jayne, J. T., Herndon, S. C., Trimborn, A. M., Williams, L. R., Wood, E. C., Middlebrook, A. M., Kolb, C. E., Baltensperger, U., and Worsnop, D. R.: Evolution of Organic Aerosols in the Atmosphere, Science, 326, 11525-1529, 2009.

Kanakidou, M., Tsigaridis, K., Dentener, F., and Crutzen, P.: Human-activity-enhanced formation of organic aerosols by biogenic hydrocarbon oxidation, J. Geophys. Res., 105(D7), 92439354, 2000.

Kanakidou, M., Seinfeld, J. H., Pandis, S. N., Barnes, I., Dentener, F. J., Facchini, M. C., Van Dingenen, R., Ervens, B., Nenes, A., Nielsen, C. J., Swietlicki, E., Putaud, J. P., Balkanski, Y., Fuzzi, S., Horth, J., Moortgat, G. K., Winterhalter, R., Myhre, C. E. L., Tsigaridis, K., Vignati, E., Stephanou, E. G., and Wilson, J.: Organic aerosol and global climate modelling: a review, At- mos. Chem. Phys., 5, 1053-1123, doi:10.5194/acp-5-1053-2005, 2005.

Koch, D.: Transport and direct radiative forcing of carbonaceous, J. Geophys. Res. , 106, 20-311, 2001.

Koch, D., Jacob, D., Tegen, I., Rind, D., and Chin, M.: Tropospheric sulfur simulation and sulfate direct radiative forcing in the Goddard Institute for Space Studies general circulation model, J. Geophys. Res.-Atmos., 104, 23799-23822, 1999.

Kroll, J. H., Donahue, N. M., Jimenez, J. L., Kessler, S. H., Canagaratna, M. R., Wilson, K. R., Altieri, K. E., Mazzoleni, L. R., Wozniak, A. S., Bluhm, H., Mysak, E. R., Smith, J. D., Kolb, C. E., and Worsnop, D. R.: Carbon oxidation state as a metric for describing the chemistry of atmospheric organic aerosol, Nat. Chem., 3, 133-139, doi:10.1038/nchem.948, 2011.

Lack, D. A., Tie, X. X., Bofinger, N. D., Wiegand, A. N., and Madronich, S.: Seasonal variability of secondary organic aerosol: A global modeling study, J. Geophys. Res., 109, D03203, doi:10.1029/2003JD003418, 2004.

Lane, T., Donahue, N., and Pandis, S.: Simulating secondary organic aerosol formation using the volatility basis-set approach in a chemical transport model, Atmos. Environ., 42, 7439-7451, 2008.

Lee, B. H., Kostenidou, E., Hildebrandt, L., Riipinen, I., Engelhart, G. J., Mohr, C., DeCarlo, P. F., Mihalopoulos, N., Prevot, A. S. H., Baltensperger, U., and Pandis, S. N.: Measurement of the ambient organic aerosol volatility distribution: application during the Finokalia Aerosol Measurement Experiment (FAME2008), Atmos. Chem. Phys., 10, 12149-12160, doi:10.5194/acp10-12149-2010, 2010.

Liao, H. and Seinfeld, J.: Global impacts of gas-phase chemistryaerosol interactions on direct radiative forcing by anthropogenic aerosols and ozone, J. Geophys. Res., 110, D18208, doi:10.1029/2005JD005907, 2005.

Liao, H., Adams, P., Chung, S., Seinfeld, J., Mickley, L., and Jacob, D.: Interactions between tropospheric chemistry and aerosols in a unified general circulation model, J. Geophys. Res., 108, D14001 doi:10.1029/2001JD001260, 2003.

Liao, H., Seinfeld, J., Adams, P., and Mickley, L.: Global radiative forcing of coupled tropospheric ozone and aerosols in a unified general circulation model, J. Geophys. Res., 109, D16207, doi:10.1029/2003JD004456, 2004.

Liousse, C., Penner, J., Chuang, C., Walton, J., Eddleman, H., and Cachier, H.: A global three-dimensional model study of carbonaceous aerosols, J. Geophys. Res.-Atmos., 101, 19411-19432, 1996.

Miracolo, M., Presto, A., Lambe, A., Hennigan, C., Donahue, N., Kroll, J., Worsnop, D., and Robinson, A.: Photo-Oxidation of Low-Volatility Organics Found in Motor Vehicle Emissions: Production and Chemical Evolution of Organic Aerosol Mass, Environ. Sci. Technol., 44, 16305-16327, 2010.

Murphy, B. and Pandis, S.: Simulating the formation of semivolatile primary and secondary organic aerosol in a regional chemical transport model., Environ. Sci. Technol., 43, 4722, 2009.

Ng, N. L., Kroll, J. H., Chan, A. W. H., Chhabra, P. S., Flagan, R. C., and Seinfeld, J. H.: Secondary organic aerosol formation from m-xylene, toluene, and benzene, Atmos. Chem. Phys., 7, 3909-3922, doi:10.5194/acp-7-3909-2007, 2007.

Pankow, J.: An absorption model of gas/particle partitioning of organic compounds in the atmosphere, Atmos. Environ., 28, 185- 
188, 1994.

Park, R., Jacob, D., Chin, M., and Martin, R.: Sources of carbonaceous aerosols over the United States and implications for natural visibility, J. Geophys. Res., 108(D12), 4355, doi:10.1029/2002JD003190, 2003.

Park, R., Jacob, D., Kumar, N., and Yantosca, R.: Regional visibility statistics in the United States: Natural and transboundary pollution influences, and implications for the Regional Haze Rule, Atmos. Environ., 40, 5405-5423, 2006.

Penner, J., Chuang, C., and Grant, K.: Climate forcing by carbonaceous and sulfate aerosols, Climate Dynam., 14, 839-851, 1998.

Presto, A., Miracolo, M., Donahue, N., and Robinson, A.: Secondary organic aerosol formation from high- $\mathrm{NO}_{\mathrm{x}}$ photooxidation of low volatility precursors: n-alkanes, Environ. Sci. Technol., 44, 2029-2034, 2010.

Pye, H. O. T. and Seinfeld, J. H.: A global perspective on aerosol from low-volatility organic compounds, Atmos. Chem. Phys., 10, 4377-4401, doi:10.5194/acp-10-4377-2010, 2010.

Rind, D. and Lerner, J.: Use of on-line tracers as a diagnostic tool in general circulation model development 1 . Horizontal and vertical transport in the troposphere, J. Geophys. Res.-Atmos., 101, 12667-12683, 1996.

Rind, D., Lerner, J., Shah, K., and Suozzo, R.: Use of on-line tracers as a diagnostic tool in general circulation model development 2 . Transport between the troposphere and stratosphere, J. Geophys. Res.-Atmos., 104, 9151-9167, 1999.

Robinson, A., Donahue, N., Shrivastava, M., Weitkamp, E., Sage, A., Grieshop, A., Lane, T., Pierce, J., and Pandis, S.: Rethinking organic aerosols: Semivolatile emissions and photochemical aging, Science, 315, 1259-1262, 2007.

Robinson, A. L., Grieshop, A. P., Donahue, N. M., and Hunt, S. W.: Updating the Conceptual Model for Fine Particle Mass Emissions from Combustion Systems, J. Air Waste Manage., 60, 1204-1222, 2010.

Sage, A. M., Weitkamp, E. A., Robinson, A. L., and Donahue, N. M.: Evolving mass spectra of the oxidized component of organic aerosol: results from aerosol mass spectrometer analyses of aged diesel emissions, Atmos. Chem. Phys., 8, 1139-1152, doi:10.5194/acp-8-1139-2008, 2008.

Schauer, J., Kleeman, M., Cass, G., and Simoneit, B.: Measurement of emissions from air pollution sources. 2. C1 through C30 organic compounds from medium duty diesel trucks, Environ. Sci. Technol., 33, 1578-1587, 1999.

Schauer, J., Kleeman, M., Cass, G., and Simoneit, B.: Measurement of Emissions from Air Pollution Sources. 3. C1-C29 Organic Compounds from Fireplace Combustion of Wood, Environ. Sci. Technol., 35, 1716-1728, 2001.

Schauer, J., Kleeman, M., Cass, G., and Simoneit, B.: Measurement of Emissions from Air Pollution Sources. 5. C1- C32 Organic Compounds from Gasoline-Powered Motor Vehicles, Environ. Sci. Technol., 36, 1169-1180, 2002.

Schichtel, B., Malm, W., Bench, G., Fallon, S., McDade, C., Chow, J., and Watson, J.: Fossil and contemporary fine particulate carbon fractions at 12 rural and urban sites in the United States, J. Geophys. Res., 113, D02311, doi:10.1029/2007JD008605, 2008.

Shrivastava, M., Lane, T., Donahue, N., Pandis, S., and Robinson, A.: Effects of gas particle partitioning and aging of primary emissions on urban and regional organic aerosol concentrations, J. Geophys. Res.-Atmos., 113, D18301,
doi:10.1029/2007JD009735, 2008.

Song, C., Zaveri, R., Alexander, M., Thornton, J., Madronich, S., Ortega, J., Zelenyuk, A., Yu, X., Laskin, A., and Maughan, D.: Effect of hydrophobic primary organic aerosols on secondary organic aerosol formation from ozonolysis of a-pinene, Geophys. Res. Lett., 34, L20803, doi:10.1029/2007GL030720, 2007.

Szidat, S.: Radiocarbon Analysis of Carbonaceous Aerosols: Recent Developments, CHIMIA International Journal for Chemistry, 63, 157-161, 2009.

Tsigaridis, K. and Kanakidou, M.: Global modelling of secondary organic aerosol in the troposphere: a sensitivity analysis, Atmos. Chem. Phys., 3, 1849-1869, doi:10.5194/acp-3-1849-2003, 2003.

Tsimpidi, A., Karydis, V., Zavala, M., Lei, W., Molina, L., Ulbrich, I., Jimenez, J., and Pandis, S.: Evaluation of the volatility basisset approach for the simulation of organic aerosol formation in the Mexico City metropolitan area, Evaluation, 9, 13693-13737, 2009.

Turpin, B. and Lim, H.: Species contributions to PM2. 5 mass concentrations: Revisiting common assumptions for estimating organic mass, Aerosol Sci. Technol., 35, 602-610, 2001.

van der Werf, G. R., Randerson, J. T., Giglio, L., Collatz, G. J., Kasibhatla, P. S., and Arellano Jr., A. F.: Interannual variability in global biomass burning emissions from 1997 to 2004, Atmos. Chem. Phys., 6, 3423-3441, doi:10.5194/acp-6-3423-2006, 2006.

Volkamer, R., Jimenez, J., San Martini, F., Dzepina, K., Zhang, Q., Salcedo, D., Molina, L., Worsnop, D., and Molina, M.: Secondary organic aerosol formation from anthropogenic air pollution: Rapid and higher than expected, Geophys. Res. Lett., 33, L17811, doi:10.1029/2006GL026899, 2006.

Weber, R., Orsini, D., Daun, Y., Lee, Y., Klotz, P., and Brechtel, F.: A particle-into-liquid collector for rapid measurement of aerosol bulk chemical composition, Aerosol Sci. Technol., 35, 718-727, 2001.

Wesley, M.: Parameterization of surface resistance to gaseous dry deposition in regional numerical models, Atmos. Environ., 16, 1293-1304, 1989.

Zhang, Q., Worsnop, D. R., Canagaratna, M. R., and Jimenez, J. L.: Hydrocarbon-like and oxygenated organic aerosols in Pittsburgh: insights into sources and processes of organic aerosols, Atmos. Chem. Phys., 5, 3289-3311, doi:10.5194/acp-5-32892005, 2005.

Zhang, Q., Jimenez, J., Canagaratna, M., Allan, J., Coe, H., Ulbrich, I., Alfarra, M., Takami, A., Middlebrook, A., Sun, Y., Dzepina, K., Dunlea, E., Docherty, K., DeCarlo, P. F., Salcedo, D., Onasch, T., Jayne, J. T., Miyoshi, T., Shimono, A., Hatakeyama, S., Takegawa, N., Kondo, Y., Schneider, J., Drewnick, F., Borrmann, S., Weimer, S., Demerjian, K., Williams, P., Bower, K., Bahreini, R., Cottrell, L., G riffin, R. J., Rautiainen, J., Sun, J. Y., Zhang, Y. M., and Worsnop, D. R.: Ubiquity and dominance of oxygenated species in organic aerosols in anthropogenicallyinfluenced Northern Hemisphere midlatitudes, Geophys. Res. Lett., 34, L13801, doi:10.1029/2007GL029979, 2007. 